\title{
Encrustation patterns on Late Cretaceous (Turonian) echinoids from southern Poland
}

\author{
Tomasz Borszcz $\cdot$ Piotr Kuklinski $\cdot$ Michał Zatoń
}

Received: 15 December 2011/ Accepted: 28 June 2012/ Published online: 26 July 2012

(C) The Author(s) 2012. This article is published with open access at Springerlink.com

\begin{abstract}
This study focuses on sclerobionts from a large collection of epibenthic echinoids ( $>2,000$ specimens) of the genera Conulus and Camerogalerus. Samples were collected from five localities in southern Poland (Polish Jura and Miechów Trough), where Turonian carbonates with terrigenous input are exposed. Low intensity (mean ca. $5 \%$, maximum ca. $10 \%$ ) and slight encrustation ("loosening effect") exclusively by episkeletozoans probably resulted from low productivity of encrusters while the importance of other factors cannot be excluded unambiguously. Echinoids served as a main substratum and after death formed shellgrounds ('echinoid carpet') offering abundant benthic islands for encrusters in an otherwise soft-bottom environment. The moderate abundance but low-diversity assemblage is represented by bivalves, sedentary polychaetes, foraminifera, bryozoans, corals, and
\end{abstract}

Piotr Kuklinski and Michał Zatoń contributed equally to the paper.

Electronic supplementary material The online version of this article (doi:10.1007/s10347-012-0319-z) contains supplementary material, which is available to authorized users.

T. Borszcz $(\bowtie) \cdot$ P. Kuklinski

Institute of Oceanology, Polish Academy of Sciences,

Powstańców Warszawy 55, 81-712 Sopot, Poland

e-mail: tomekb@iopan.gda.pl

P. Kuklinski

e-mail: kuki@iopan.gda.pl

P. Kuklinski

Department of Zoology, Natural History Museum,

Cromwell Road, London SW7 5BD, UK

M. Zatoń

Faculty of Earth Sciences, University of Silesia,

Będzińska 60, Sosnowiec 41-200, Poland

e-mail: mzaton@wnoz.us.edu.pl sponges. This assemblage is similar to a nearly contemporaneous assemblage from the Bohemian Basin. The presence of numerous spirorbins offers insights into their early evolution and may indicate that their first peak in abundance after origination was not prior to the earliest Turonian. This is regarded as one of the important ecological steps towards the rise of modern sclerobiont communities. Encruster diversities are independent of their abundance and, as shown in our novel planar projections, lateral parts of tests were preferentially encrusted. This pattern is explained by the combination of largest flat area and stable orientation. Encrusting bivalves and serpulids dominated hard substrate environments in the Turonian of Poland.

Keywords Echinoids - Encrusters · Ecology ·

Cretaceous · Turonian $\cdot$ Poland

\section{Introduction}

Encrustation, also termed fouling or epibiosis (see e.g., Wahl 1989; Harder 2009) is a widespread phenomenon in marine environments. It is long-ranging, extending back to Cambrian times, and has received growing interest among both paleontologists and neontologists (e.g., Brett 1988; Wahl 1989; 2009; Lescinsky 2001; Taylor and Wilson 2003; Kukliński 2009; and references cited therein). In many instances, encrusting organisms provide biological, taphonomic, and ecologic information often not available from other sources in the fossil record (Lescinsky 2001). Encrusters are also a powerful tool for recognizing discontinuity surfaces, tracking the taphonomic history of organisms, for paleoenvironmental reconstructions, inferring life styles of host organisms, and for studying 
biological interactions (see Taylor and Wilson 2003 for examples).

When compared to other biogenic substrates such as mollusks (e.g., Taylor 1979; Lescinsky 1993; McKinney 1996; Lescinsky et al. 2002) or brachiopods (e.g., Bordeaux and Brett 1990; Lescinsky 1997; Rodland et al. 2004), echinoids have been rarely studied as potential substrates for encrustation. To date, there have been few studies on encrustation patterns on echinoids in general (e.g., Hammond 1988; Nebelsick et al. 1997; Schneider 2003; Santos and Mayoral 2008; Zamora et al. 2008).

In the present paper, we focus on encrustation patterns on Cretaceous echinoids from Poland. Although Polish Cretaceous echinoids have been the subject of paleontological investigations for more than a hundred of years (e.g., Zaręczny 1878; Kongiel 1939; Popiel-Barczyk 1958; Mączyńska 1984; Jagt et al. 2004; Jagt and Salamon 2006; Olszewska-Nejbert 2007; Borszcz et al. 2008; Jagt and Kin 2010), records of their encrustation are rather scanty compared to the abundance of these fossils. To date, only octocoral bases (Małecki 1982) and bryozoans (Dzik 1975) encrusting Polish Cretaceous echinoid tests have been taxonomically investigated, while Kudrewicz (1992) illustrated some epibionts on echinoids and used them for taphonomic reconstruction of the Santonian environment of southern Poland.

Here we provide new data concerning the encrustation patterns of Turonian echinoid tests. This time interval is of interest because it follows the controversial CenomanianTuronian extinction event (e.g., Smith et al. 2001). Epibionts may add new data and other perspectives in this regard (cf. Lescinsky 2001; Fraiser 2011). Qualitative and quantitative analyses are undertaken on a large sample size, revealing diversity patterns, a distribution, taphonomy, and ecology of the encrusters. An interpretation of the paleoenvironment of the encrusted echinoids is also given.

\section{Geological setting}

Paleogeographic background

During Late Cretaceous times, the study area was located at ca. $45^{\circ} \mathrm{N}$ (e.g., Golonka 2000) and covered by an epicontinental sea as a result of the extensive transgression that had begun in the Albian (see e.g., Cieśliński 1959; Dadlez 1989; Dadlez et al. 1998; Marcinowski 1974). The study area is confined to the southeastern margin of the Central European Basin as part of the German-Polish Cretaceous Basin, also called the Polish Basin (e.g., Marcinowski and Radwański 1983; Marcinowski and Gasiński 2002).
In Poland, Upper Cretaceous deposits are exposed primarily in a few regions (Fig. 1a), all being under the influence of the North European Faunal Province. One of these, the Miechów Trough, is the southern part of a great structure known as the Szczecin-Łódź-Miechów Trough with the Polish Jura Chain as its western border. In the Miechów Trough, the transgressive Upper Cretaceous deposits are well developed, but some gaps are also evident (e.g., Marcinowski 1970, 1974; Marcinowski and Radwański 1983; Rutkowski 1965).

Studied localities

Five localities with Turonian echinoids were investigated. They are all situated in southern Poland (Fig. 1b), partly in the Miechów Trough and Polish Jura Chain, including the Kraków Upland as their southern tip and represent a 35-km-long transect. These localities (Fig. 1c, d) are represented by abandoned quarries and/or temporary trenches, where such deposits are relatively well exposed and fossiliferous.

\section{Glanów}

The outcrop is located less than $10 \mathrm{~km}$ southeast of the city of Wolbrom. During the fieldwork, $6 \mathrm{~m}$ of Upper Cretaceous sedimentary rocks, resting on Upper Jurassic (Oxfordian) limestones (e.g., Sujkowski 1926; Marcinowski 1972, 1974), were uncovered. The strata were dated as Cenomanian and Turonian on the basis of inoceramid and ammonite faunas (e.g., Marcinowski 1974; Walaszczyk 1992). The investigated Lower Turonian deposits, situated within the Mytiloides labiatus Zone, are ca. $4 \mathrm{~m}$ thick and developed as laminated limestones (wackestones) covered by poorly lithified sandy limestones. This outcrop is well known for its abundant and diverse fossils (e.g., Kongiel 1939; Mączyńska 1958; Popiel-Barczyk 1958; Marcinowski 1974; Borszcz et al. 2008; Salamon et al. 2009). Echinoids are exceptionally abundant about $1 \mathrm{~m}$ above the Cenomanian-Turonian boundary (see also Borszcz et al. 2008).

\section{Trojanowice}

Five meters of Turonian deposits, represented by the Lower Turonian M. labiatus Zone and the Middle and/or Upper Turonian (Inoceramus cotellatus and/or I. lamarcki and I. costellatus zones; see Walaszczyk 1992), are exposed there. The section is represented by strongly lithified massive limestones, sandy limestones, and cherts, followed by pelitic limestones (Kudrewicz and Olszewska-Nejbert 1997). 


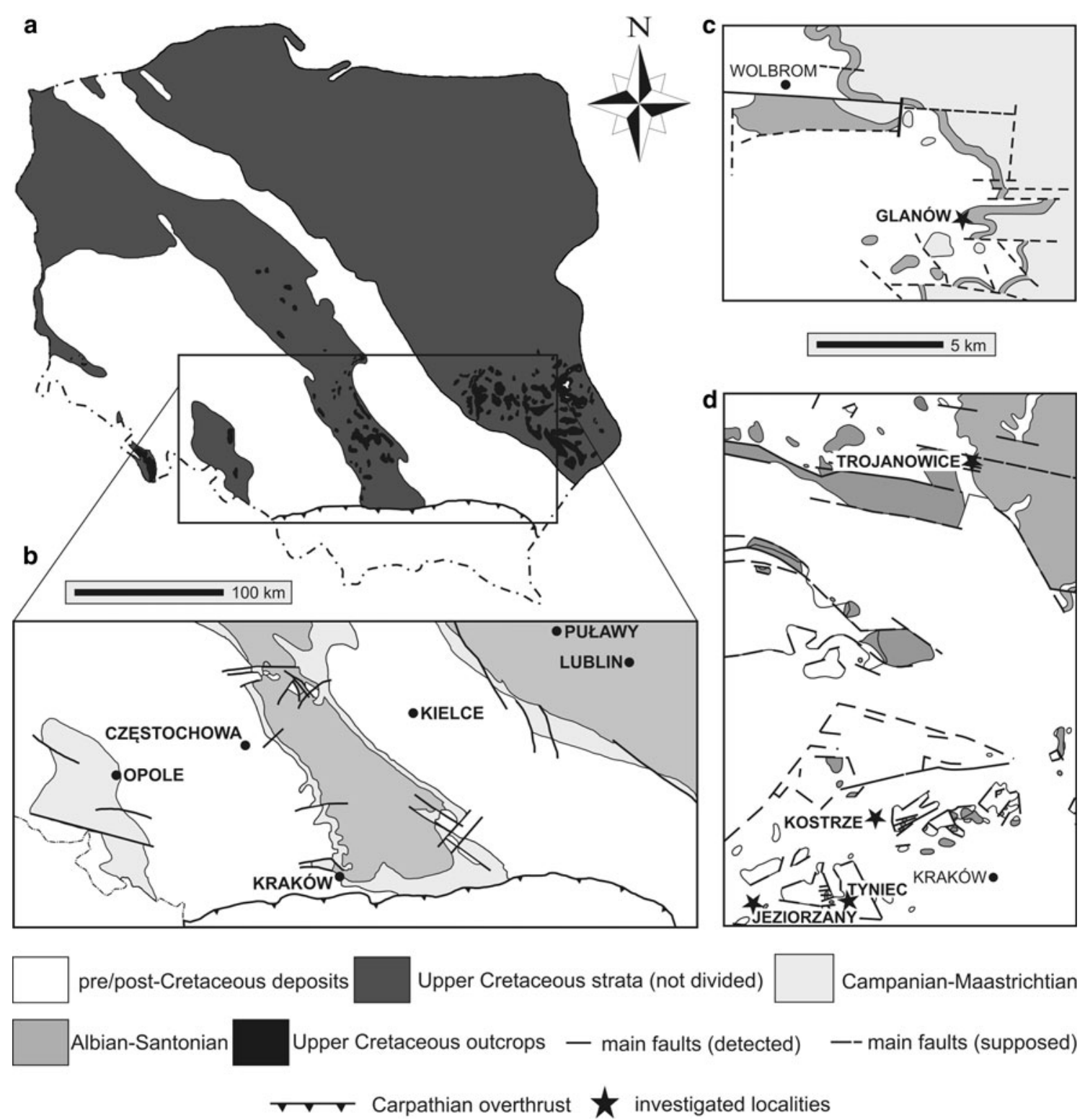

Fig. 1 Geological map of Poland without Cenozoic cover (a) showing the region of interest (b) and investigated localities (c, d). Compiled from Gradziński (1972), Walaszczyk (1992) and Borszcz et al. (2008)

\section{Kostrze}

Specimens were recovered from a trench in Turonian strata developed as sandy limestones with quartz pebbles. Alexandrowicz (1954, pp. 372) dated the outcrops based on the presence of Inoceramus cf. lamarcki and I. cuvieri, indicating a highest Middle Turonian (I. lamarcki Zone) age (e.g., Olszewska-Nejbert 2007).

\section{Tyniec}

An abandoned quarry exposes highly karstified Turonian strata less than $1 \mathrm{~m}$ thick and comprising limestones with an admixture of quartz grains (see also e.g., Gradziński 1972). Representing the Lower Turonian M. labiatus Zone (Walaszczyk 1992), the deposits contain abundant echinoids of Conulus subrotundus.

\section{Jeziorzany}

This outcrop, also known as Ściejowice (see Alexandrowicz 1954), is one of the most southerly located Upper Cretaceous sections in Poland and comprises poorly cemented limestones with quartz pebbles and occasional manganese concretions. Turonian deposits are up to $1 \mathrm{~m}$ thick and have been assigned to the Helvetoglobotruncana 
helvetica Zone as based on foraminifera (Zofia Dubicka, pers. comm.), thus indicating an Early to Middle Turonian age (Peryt 1980).

\section{Materials and methods}

\section{Material}

The specimens were collected both by hand picking and bulk sampling. Bulk samples were processed using repeated freezing and thawing in a solution of glauber salts. In total, 2,094 specimens were collected. Among these, 1,882 specimens came from Glanów, where nearly 300 specimens are represented by Camerogalerus minimus, and the rest by Conulus subrotundus. A further 79 specimens come from Tyniec, 69 from Jeziorzany, 40 from Kostrze, and 24 from Trojanowice; all of these are Conulus subrotundus. To our best knowledge, this material is the largest used in a study of echinoid encrustation to date. For comparative purposes we also screened associated bio- and lithoclasts, as well as the residues from sieving. Among these, we focused on other echinoderms (crinoid, ophiuroid, and asteroid remains), brachiopods, bivalves (including a few tens of inoceramid shells), fish teeth and quartz pebbles (90 specimens) and slabs of host sediment with encrusted tests, with a surface area from a few to a few dozens of $\mathrm{cm}^{2}$.

The material was first cleaned and then carefully inspected using a stereo-microscope. Selected specimens were photographed using a digital camera and selected encrusters were scanned using a Philips XL 30 Environmental Scanning Electron Microscope (ESEM) housed in the Faculty of Earth Sciences, Sosnowiec. All material is deposited in the Department of Paleontology and Stratigraphy, University of Silesia, Sosnowiec, Poland (GIUS 9-3478 and GIUS 9-3580).

\section{Analytical methods}

Two metrics were used to evaluate epibiont abundance. In the first method, the proportions of particular taxa in the assemblage are expressed as the number of individuals of a particular taxon, and in the second by the number of tests encrusted by this taxon. For the purpose of statistical analysis, we quantified epibiont associations and dispersions, with five and three individuals as a mean, respectively.

Measurements of sizes of epibionts and echinoids were undertaken using a caliper. For the former, bivalves (their attachment bases) and spirorbins were selected as examples. For measurements of substrate sizes, only wellpreserved echinoids allowing precise measurements of width, length, and height were incorporated.
Descriptive terminology follows Taylor and Wilson (2002, 2003), and partly Wahl (1989; see also Harder 2009). Encrustation intensity (see also Rodland et al. 2004) was divided into total (mean) and partial, defined as the ratio of encrusted to non-encrusted bioclasts for the whole collection of echinoids (total encrustation intensity) and for respective localities (partial encrustation intensity).

Encruster taxa richness (orders or operational taxonomic units) in this study refer to a micro-alpha diversity on a single echinoid test, an alpha diversity referring to a single locality, and total diversity of all encrusting taxa from all of the localities. Counting higher taxonomic units rather than species is supported by a recent finding that relatively little information is lost when such surrogacy is used (e.g., Włodarska-Kowalczuk and Kędra 2007).

For testing relationships between epibionts and substrate size we used three measurements (width, length, and height). This method was used rather than surface or cubic measurements, which has been successfully applied to various other substrates (e.g., Wilson and Taylor 2001; Grzelak and Kukliński 2010; Zatoń et al. 2011), because the state of preservation of the material did not permit the latter.

We used linear regression $\left(R^{2}\right)$ for analysis of relationships between, for example, number of encrusters, species richness, and echinoid test size. ANOVA (F) was used to explore differences between abundance, species richness, and echinoid tests of various states of preservation. To improve normality and homogeneity of the data, the analysis was followed by $\log (x+1)$ transformation. The nonparametric Kruskal-Wallis test $(\mathrm{H})$ was used for analysis of the differences between encrusters on tests of different echinoid species, different sectors of echinoid tests, and for investigating microstratigraphic changes in the composition of encrusters. All datasets used in the statistical analyses are derived from our database (see Electronic Supplementary Material 1; ESM 1) and are available from the authors upon request. All statistical analyses and graphs were carried out using the Statistica 8.0 and PAST software (Hammer et al. 2001).

\section{Planar projections}

To show the spatial distribution of epibionts on their substrates, we propose a new planar projection, conceptually similar to but more advanced than those used by Nebelsick (1996) or Santos and Mayoral (2008). The previous types of projections or contour diagrams are frequently used for patterns of encrustation, bioerosion, or drilling predation (e.g., Bottjer 1982; Lescinsky 1997; Nebelsick et al. 1997; Santos and Mayoral 2008; Zamora et al. 2008; Sørensen and Surlyk 2010) but are inadequate for our material as they are designed for flat substrates in contrast to the nearly 
spherical echinoids studied here. The only exception is Hammond (1988), who used 3-D stereographic projections and goniometry-based recording of epibionts. However, during the course of this study, his unpublished $\mathrm{PhD}$ thesis was unknown to us.

The echinoid tests were divided into 50 unequal sectors, defined by horizontal lines marked by sutures of columns and five arbitrary vertical lines (see Fig. 2 for explanations). Each sector (Fig. 2a-c) is represented on the circle of projection (Fig. 2d) by two coordinates, one vertical and one horizontal. The five vertical zones are denoted A to E, supplying the first coordinate (Fig. 2b). The second coordinate consists of one of ten horizontal zones, labeled 1-5 and I-V (Fig. 2c). Arabic numerals refer to interambulacral columns and Roman numerals to ambulacra. If denoted, for example, only as A or IA this signifies that the state of preservation of the echinoid does not allow for a more precise specification. Additionally, we also included the peristome, periproct, and apical disc as distinct sectors, even though these were rarely colonized. Thus, in total, 53 sectors were distinguished. Direction of numbering of the columns is standard (compare Santos and Mayoral 2008). In some instances, an encrusting organism crosses two sectors, in which case the sector recorded was that which included more than $50 \%$ of the encruster. However, when more than $50 \%$ of two sectors was covered by an encruster, the encruster was counted twice, once for each sector. When the epibiont or test was damaged epibiont position could not be exactly located. For example, the designation C? or CIA means that an organism settled in zone $\mathrm{C}$ but on an unknown column, or in an interambulacral column but in an unknown sector. Such cases, as with examples of encrustation of more than two sectors, were not included in the projection.

\section{Dataset}

The full dataset used for this study is provided as an Excel spreadsheet in ESM 1, and is fully explained in ESM 2. Two additional figures are included in ESM 3.

\section{Results}

Number of encrusted specimens

Of the 2,094 echinoid specimens, 193 are encrusted (see ESM3 Fig. 1). Of these, 185 encrusted echinoids come from the Glanów section, three from Tyniec, three from Jeziorzany, one from Trojanowice, and one from Kostrze. Total mean encrustation intensity is about $5 \%$ and partial intensity ranges from 2.5 to $9.83 \%$. The lowest value is from Kostrze and the highest from Glanów (ESM 3 Fig. 1).
In total, we found 271 examples of encrustation, 263 of them at Glanów and significantly fewer at the remaining localities.

Characteristics of the encrusted echinoids

Two irregular echinoid species-Conulus subrotundus and Camerogalerus minimus (Fig. 3)-are encrusted. Both species generally lived epifaunally through most of their lives (Smith 1988; for phylogeny see Kroh and Smith 2010). Conulus subrotundus (Smith and Wright 1999; Borszcz et al. 2008 for illustrations) is characterized by a globular to elliptical test, up to $50 \mathrm{~mm}$ in diameter at the ambitus, a dense tuberculation reflecting a dense canopy of spines, a small central peristome, and a periproct situated at the margin of the flattened oral side of the test. Around $10 \%$ of the collected examples of this species are encrusted. Camerogalerus minimus (for illustrations see e.g., Mączyńska 1958 or Smith and Wright 1999 among others) has a much smaller test (diameter up to $12 \mathrm{~mm}$ in the collected material) than Conulus subrotundus. It has a centrally positioned small peristome and a large periproct on the oral side, and are supported by internal buttressing. Only about $2 \%$ of the collected specimens of this species are encrusted.

These taxa are the main benthic components of Turonian deposits in the areas investigated, and thus they form characteristic biofacies manifested by great abundance (e.g., a few dozen individuals of $C$. subrotundus can be found on bedding surfaces measuring several hundred $\mathrm{cm}^{2}$ ). A few dozen $C$. minimus individuals can also be found in a $1-\mathrm{kg}$ bulk sample. This high abundance of specimens allows for the formation of an echinoid "shellground" (e.g., Dodd and Stanton 1990; Zuschin et al. 1999; Zuschin and Baal 2007). Locally, the Turonian sea floor was densely covered by dead echinoid tests forming a carpet available for colonization by encrusters.

Analysis of epibiont numbers on the two echinoid species shows no statistical difference $\left(H_{(2, \mathrm{n}=3,900)}=1.81\right.$, $p=0.404)$; therefore, results from the two echinoids are combined in subsequent analyses.

Characteristics of the encrusters

In total, ten taxa encrusted the echinoid tests. In most cases, they were identified to a higher taxonomic level (Table 1). The encruster assemblages (Table 1) include foraminifera, sponges, corals, bivalves, sedentary polychaetes and bryozoans, as well as unidentified specimens that most probably belong to the known taxa (Fig. 4). The highest diversity was found in Glanów, where all the taxa mentioned above occur. At the remaining localities, only one or two taxa were identified. Bivalves and polychaetes are 

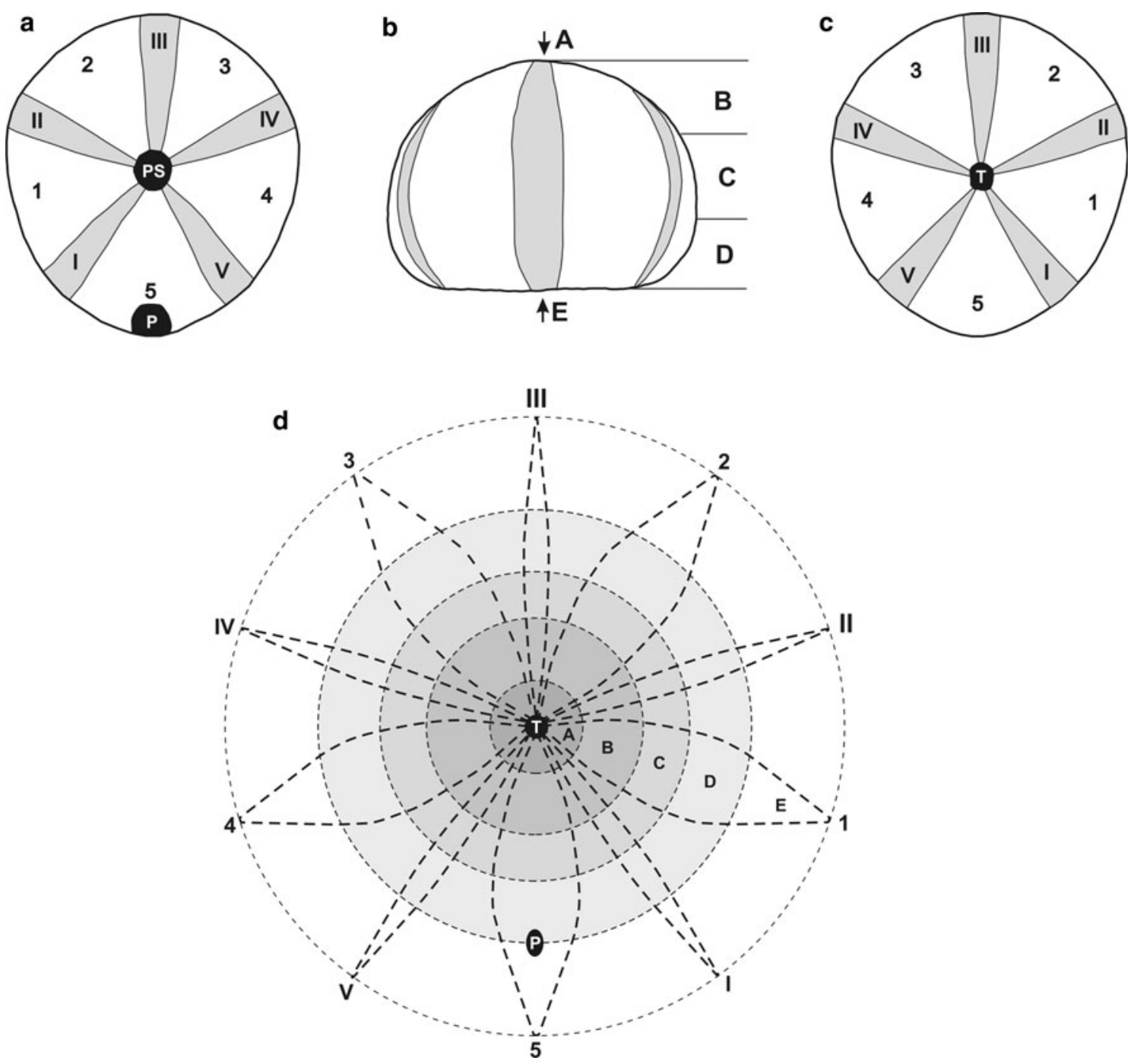

Fig. 2 Scheme of partitioning of echinoid tests for planar projections used in the present study
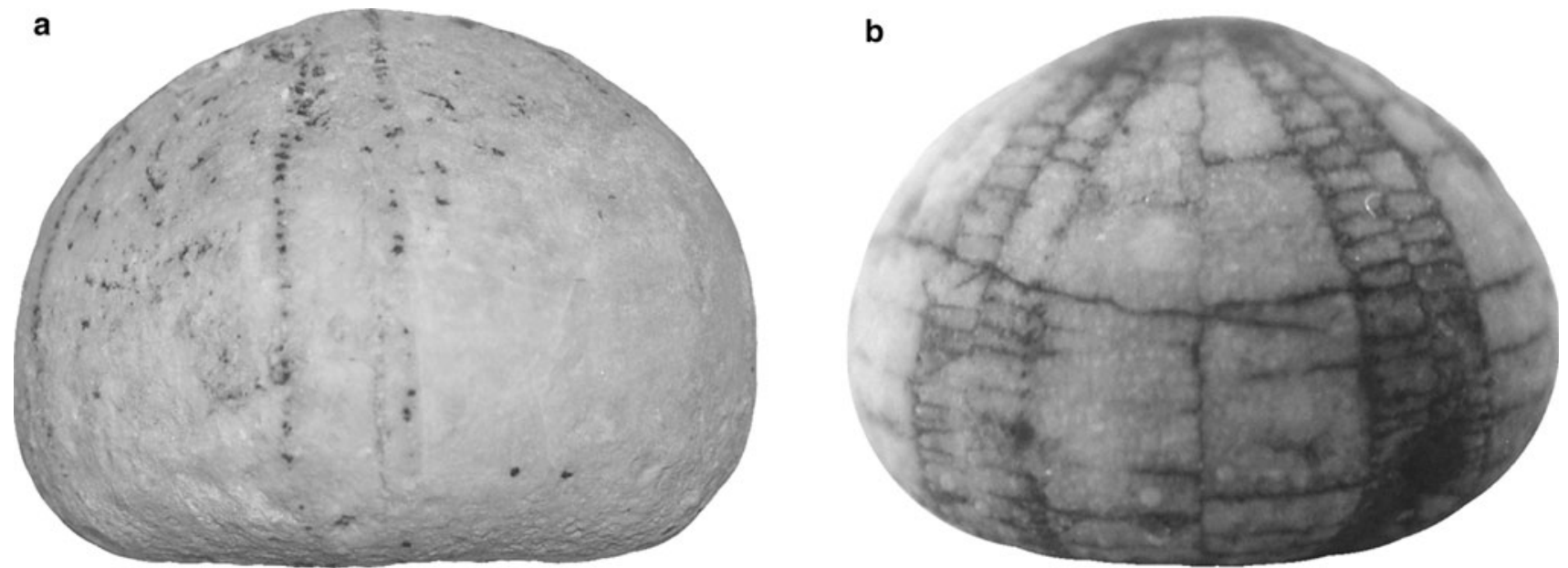

Fig. 3 Examples of investigated echinoid substrates; a Conulus subrotundus. b Camerogalerus minimus. Scale bar $1 \mathrm{~cm}$ (a) and $1 \mathrm{~mm}(\mathbf{b})$ 
among the most widely distributed organisms, while corals and bryozoans are known only from a single locality (Glanów). All assemblages are dominated by suspensionfeeders, of which the corals occupy the highest trophic level. Bryozoans and sponges are the only colonial and clonal organisms; some sabellid polychaetes were found aggregated, while the corals, foraminifera, and spirorbins are exclusively solitary. Solitary organisms dominate over colonial ones (Table 1).

The smallest encrusters are tiny agglutinating foraminifera identified as Acruliamina sp., along with other, unidentified forms. The Acruliamina specimens resemble those reported by Žitt and Nekvasilová (1996) as A. longa (see also Hercegová 1988), which is typical for Turonian nearshore environments.

Bivalves are represented by Atreta and other unidentified forms (Fig. 4a, b). Most Atreta specimens are very similar to Atreta sp. 1 of Žitt and Nekvasilová (1996), a taxon also noted by Kudrewicz (1992) encrusting Santonian echinoids from southern Poland. The unidentified bivalves may also include oyster-like forms. Only the attached valves are preserved and thus some taxonomically important features are lacking.

Bryozoans are represented by the form-genus Berenicea with millimeter-sized, sheet-like colonies (Fig. 4c). These colonies cannot be determined to the genus level due to the absence of the taxonomically crucial gonozooids (e.g., Taylor and Sequeiros 1982).

Probable sponges (Fig. 4d) are represented by an unidentified taxon, most probably a calcisponge. They are characterized by irregular and asymmetrical branches, and are among the largest encrusters within the assemblage, with branches more than $1 \mathrm{~cm}$ in diameter.

Coiled sedentary polychaetes (Fig. 4e, f) are represented by both dextrally (clockwise, Fig. 4e) and sinistrally (anticlockwise, Fig. 4f) coiled tubes of spirorbins, assigned to the genus Neomicrorbis. They are very similar to N. subrugosus from the Upper Cretaceous of western Europe (Jäger 1983, 2004). Similar forms were also noted in the Santonian of Spain by Zamora et al. (2008). It is worth noting that although true spirorbins became common in the Cenomanian (Jäger 1983; Vinn and Taylor 2007), they were not reported from around Cenomanian/Turonian boundary sections in the neighboring Czech Republic by Žitt and Nekvasilová (1996). Their presence in the Turonian of Poland in larger numbers than ever before deserves attention, reflecting an important ecological step towards the formation of modern-type encrusting communities (Zatoń and Vinn 2011).

Other polychaetes are represented by thin, smooth tubes of the calcareous sabellid Glomerula, well known from Poland and other regions (e.g., Radwańska 1996).

Table 1 List of encrusting taxa with their frequency and distribution between investigated localities

\begin{tabular}{|c|c|c|c|c|c|c|c|c|c|}
\hline \multirow[t]{3}{*}{ Taxa } & \multicolumn{4}{|l|}{ Frequency } & \multirow{2}{*}{\multicolumn{5}{|c|}{ Locality (+present/-absent) }} \\
\hline & \multicolumn{2}{|c|}{ Number of specimens } & \multicolumn{2}{|c|}{ Number of tests } & & & & & \\
\hline & Individuals & Percent $^{\mathrm{a}}$ & Individuals & Percent $^{\mathrm{a}}$ & Glanów & Trojanowice & Kostrze & Tyniec & Jeziorzany \\
\hline Bivalvia & 66 & 34 & 58 & 25 & + & - & - & + & + \\
\hline Atreta sp. & 11 & 6 & 11 & 5 & + & - & - & - & - \\
\hline Bivalvia indet. & 55 & 30 & 48 & 21 & + & - & - & + & + \\
\hline Polychaeta & $>46^{\mathrm{b}}$ & 24 & 111 & 48 & + & + & + & - & - \\
\hline Neomicrorbis sp. & 27 & 15 & 24 & 11 & + & + & - & - & - \\
\hline Serpulidae indet. & $>19^{\mathrm{b}}$ & 10 & 91 & 40 & + & - & + & - & - \\
\hline Foraminifera & 37 & 19 & 24 & 10 & + & - & - & - & + \\
\hline Acruliammina sp. & 35 & 19 & 22 & 10 & + & - & - & - & + \\
\hline Foraminifera indet. & 2 & 1 & 2 & 1 & + & - & - & - & - \\
\hline Anthozoa & 3 & 2 & 3 & 1 & + & - & - & - & - \\
\hline Octocorallia indet. & 1 & 1 & 1 & $\sim 0$ & + & - & - & - & - \\
\hline Hexacorallia indet. & 2 & 1 & 2 & 1 & + & - & - & - & - \\
\hline Bryozoa & 12 & 9 & 11 & 6 & + & - & - & - & - \\
\hline 'Berenicea' & 12 & 7 & 11 & 5 & + & - & - & - & - \\
\hline ?Porifera & 18 & 6 & 13 & 5 & + & - & - & - & + \\
\hline ?Calcispongiae indet. & 18 & 10 & 13 & 6 & + & - & - & - & + \\
\hline Epibiont indet. & 12 & 6 & 11 & 5 & + & - & - & + & - \\
\hline
\end{tabular}

${ }^{a}$ Rounded off to one percent

b Such number are lowered, because of counting method, treating multi-individual occurrences as a single individual 

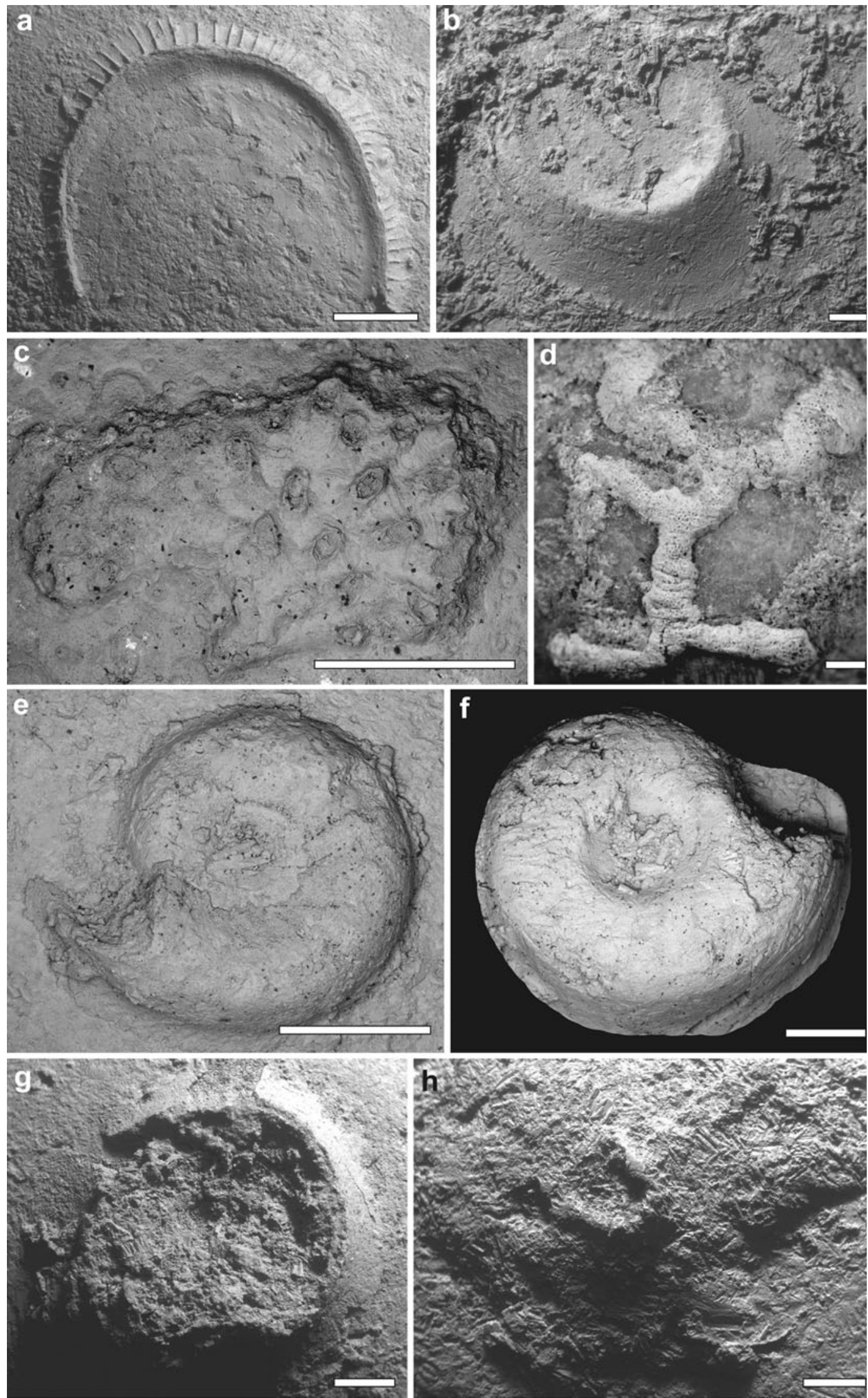
4 Fig. 4 Selected encrusters on the echinoid tests investigated: a, b Bivalves. c Cyclostome bryozoan colony. d Probable calcisponge. e, f Spirorbin Neomicrorbis sp. g, h Corals preserved as hexacoral (g) and octocoral (h) bases. All specimens come from the Lower Turonian (M. labiatus zone) of the Glanów section. $\mathbf{a}-\mathbf{c}$ and $\mathbf{e}-\mathbf{h}$ are ESEM photographs and $\mathbf{d}$ is a digital microphotograph. Scale bar $1 \mathrm{~mm}$

Corals are restricted to the Glanów section and are preserved only as bases, thus their precise identification is precluded. Both hexacorals (Fig. 4g) and octocorals (Fig. 4h) can be recognized, the latter resembling the parataxon Octobasis (Małecki 1982). Based on the co-occurring skeletons and comparisons with the literature, these hexa- and octocorals resemble the genera Parasmilia and Moltkia, respectively. They are well-known encrusters, for example in the Upper Cretaceous of England and Poland (e.g., Gale 2002; Pugaczewska 1965).

\section{Distribution of encrusters}

Nearly all surfaces of echinoid tests were utilized by encrusters (Figs. 5, 6, 7, 8) while each formed a specific "microhabitat" sensu Ronowicz et al. (2008). Lateral sides of tests were preferentially encrusted, as is shown in the plane projections (Figs. 5, 6). The periproct was found to be encrusted only on one test, where a bivalve is cemented to its rim. Looking at the entire assemblages, the highest frequency of encrustation is observed in sectors B, C, and
D in interambulacral columns (Fig. 8). Among these sectors, there are no strong preferences by particular taxonomic groups of encrusters (Fig. 6). The greatest diversity of encrusters was recorded on sectors B and C. With the exception of ambulacrum I (Fig. 7), a larger number of epibionts is observed on interambulacra than on ambulacra. This corresponds with the pattern of clypeasteroid echinoid encrustation by barnacles reported by Santos and Mayoral (2008). Trends in the distribution of a number of epibionts on echinoid test surfaces are demonstrated in Fig. 2 of ESM3. Differences in encrustation between all the sectors $\left(H_{(9, \mathrm{n}=3,450)}=151.83, \quad p<0.001\right)$ but also between horizontal $\left(H_{(4, \mathrm{n}=3,900)}=44.88, p<0.001\right)$ and lateral $\left(H_{(9, \mathrm{n}=3,450)}=48.90, p<0.001\right)$ zones were statistically significant. Comparisons of orientation of echinoids $(n=48)$ as preserved in geological sections with positions of epibionts on their tests $(n=20)$, demonstrates that in normal and lateral orientations of the tests, sectors from $\mathrm{B}$ to $\mathrm{E}$ were encrusted. In echinoids preserved inversely (top down) encrusters were noted only in sectors B and C. Moreover, in echinoids preserved "top down", encrusters are commonly dispersed.

Few tests have high encruster density and diversity (Fig. 9). More than 70 tests have only one epibiont, while tests bearing more than one encruster are significantly fewer (Fig. 9a). About 160 tests have one encrusting taxon, while those with three taxa are rare (see Fig. 9b).
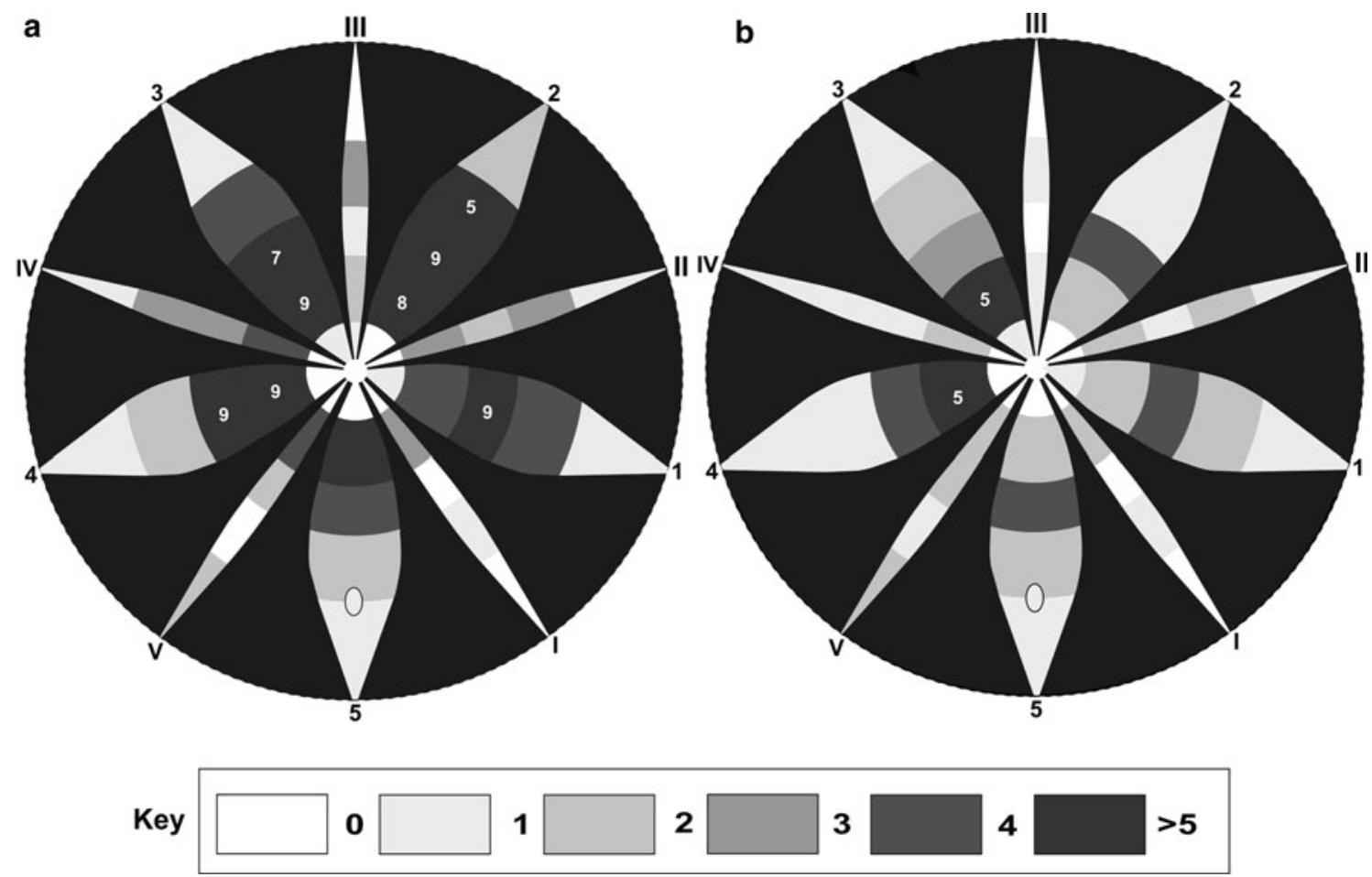

Fig. 5 Planar projections of echinoid test showing epibiont distribution, their abundance $(\mathbf{a} ; n=102)$ and taxonomic diversity $(\mathbf{b}$; for $n=89)$ 

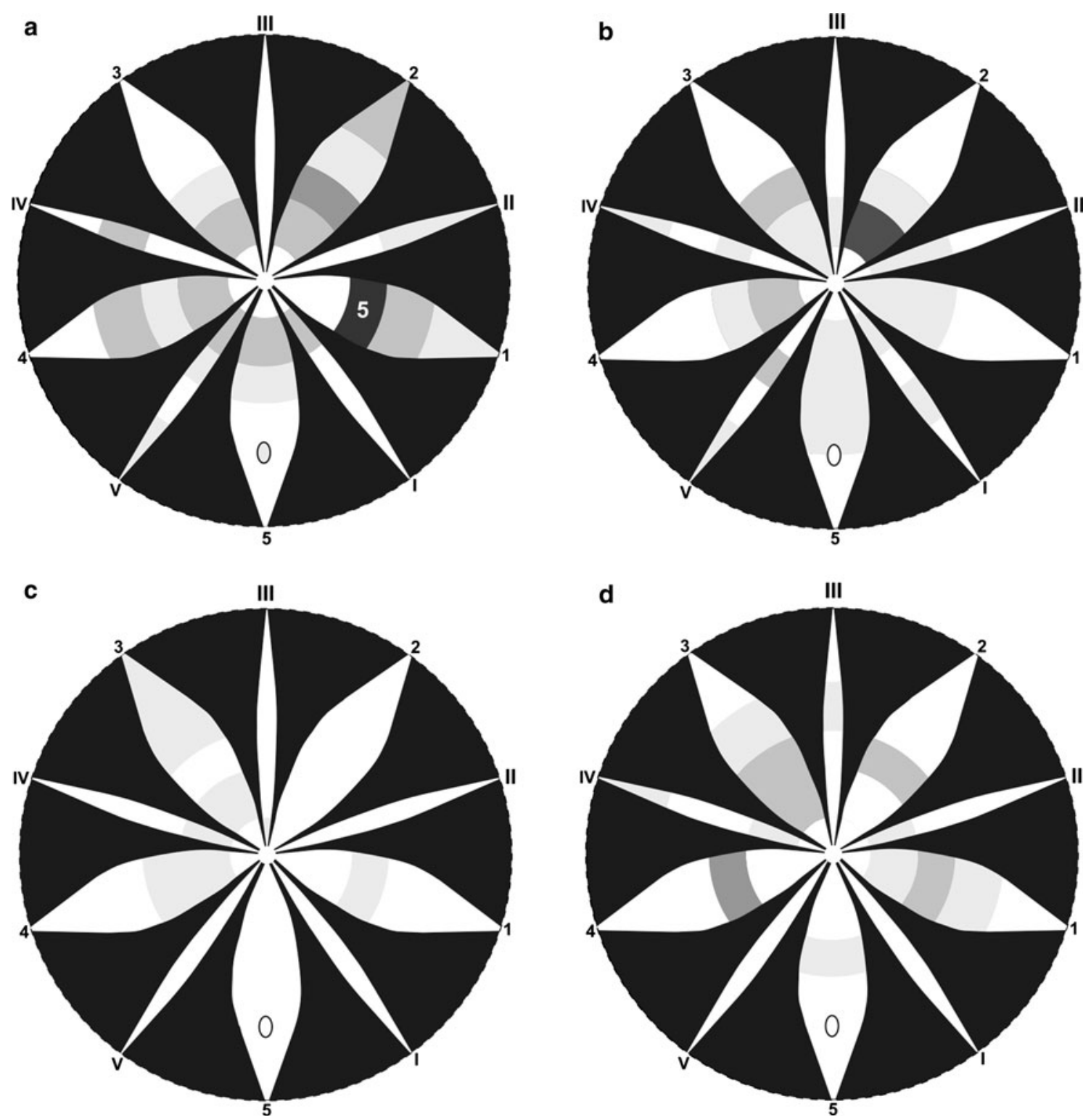

Fig. 6 Planar projections of echinoid test showing frequency of distribution of selected higher epibiont taxa: bivalves (a; $n=30)$, foraminifera $(\mathbf{b} ; n=26)$, bryozoans $(\mathbf{c} ; n=7)$ and spirorbins $(\mathbf{d} ; n=18)$. Explanations as in Fig. 5

Numerically, the most abundant encrusters are bivalves and serpulids, accompanied by foraminifera. The rest of the taxa are accessory (Fig. 10). Corals are represented by one or two specimens, while there are hundreds of individuals of bivalves and polychaetes. If encruster dominance is evaluated by the number of encrusters, bivalves $(34 \%)$, followed by polychaetes $(24 \%)$, and foraminifera (19\%) are dominant. In contrast, if dominance is evaluated by counting the number of encrusted tests, polychaetes are dominant $(48 \%)$. Polychaetes occur on nearly half of the collected tests, while bivalves encrusted $25 \%$ of the tests and foraminifera only $10 \%$.

An increase in the number of encrusted tests coincided with the decrease in the preservational state of the echinoids (Fig. 11), but this relationship was not statistically significant $\left(R^{2}=0.73, p=0.06\right)$.

No evidence of competition for space among the preserved encrusters was found. The single example of a bivalve overgrown by a serpulid clearly occurred after death of the bivalve as the serpulid grows over the interior surface of the cemented valve, postdating disarticulation of the bivalve (Fig. 4b). Other types of encrustation (Fig. 12), transient between a test and sediment or confined only to sediment also were noted in our material. Epibionts are variously preserved (Fig. 13), the most common being fragmentary preservation, followed by preserved attachment bases and their remains, followed by complete specimens. Such a range of preservations is indicative of 


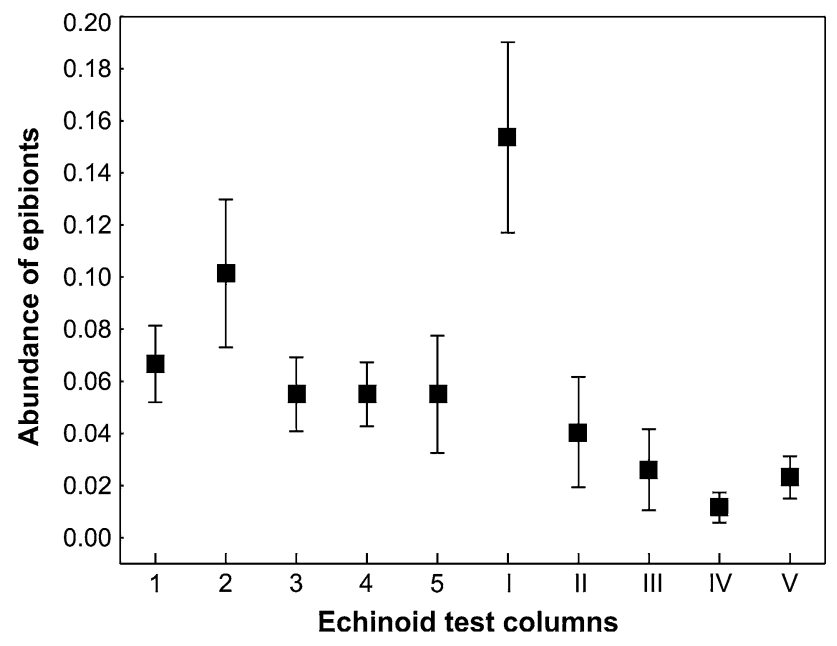

Fig. 7 Mean values (with standard error) of epibiont abundance in particular echinoid test columns. Explanation of symbols in Fig. 3

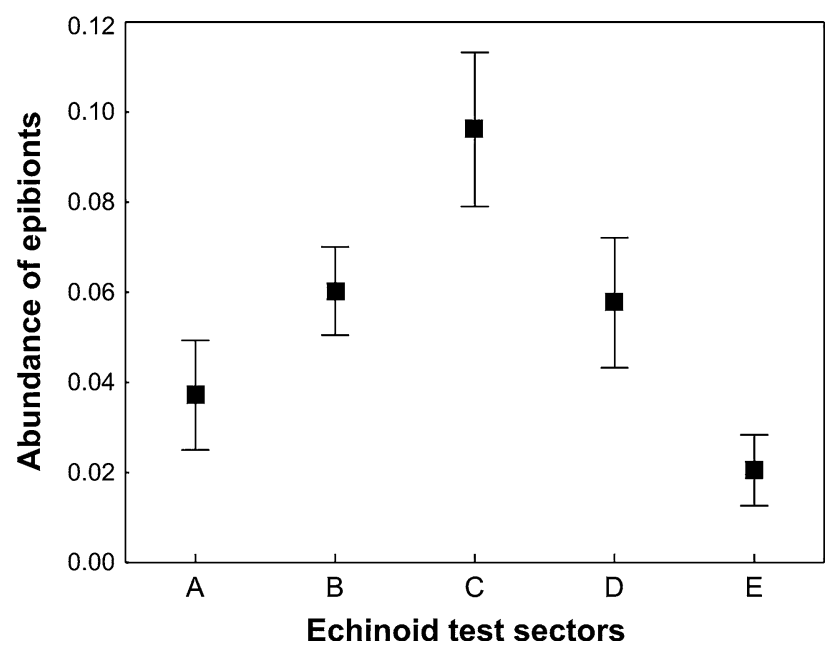

Fig. 8 Mean values (with standard error) of epibiont abundance in particular echinoid test sectors. Explanation of symbols in Fig. 3

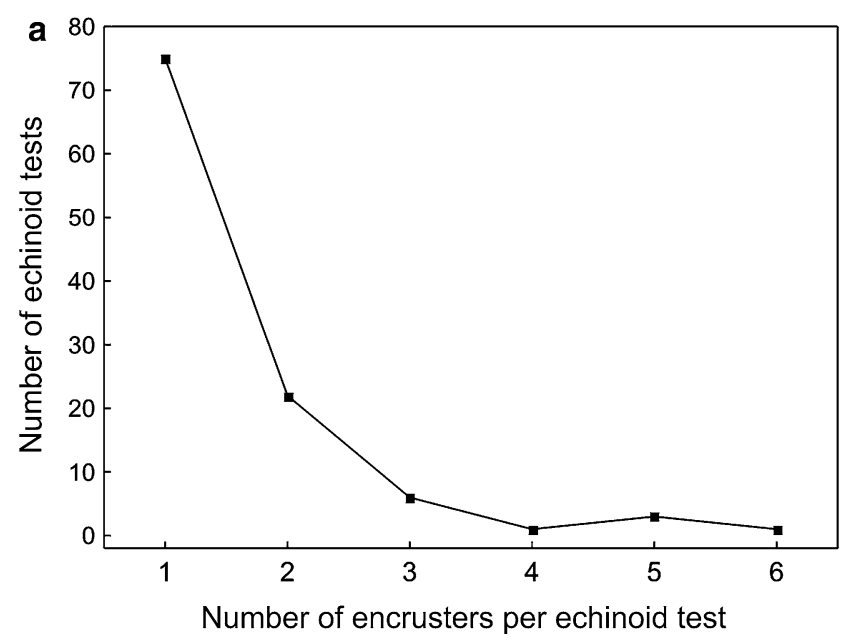

Fig. 9 Abundance (a) and diversity (b) of encrusters per echinoid test shallow-water sites (e.g., Richardson-White and Walker 2011). As in the encrusters, fragmentation and other damage can be recognized in the host echinoids (see also Zuschin et al. 2003), comprising disarticulation, dissolution, corrasion (e.g., Brett and Baird 1986; Hageman et al. 2004), pitting (e.g., Radwański 1965), flattening (e.g., Briggs 1990; Hageman et al. 2004), chalky surfaces (e.g., Kowalewski 1990; Smith and Nelson 2003), and karstification. This preservational variation in both echinoids and their encrusters suggests different taphonomic scenarios. In addition to whole articulated tests, we also found flattened, fragmented, and abraded/partially dissolved specimens. In most cases, fragmentation, as well as flattening of echinoids, can be ascribed to compaction, which is also underlined by signs of pitting. There is no strong relationship between the number of encrusted tests and their preservation. This excludes rapid burial after encrustation and suggests that time of exposure is unrelated to encrustation intensity. Additionally, it also points to a strong influence of diagenetic processes, whereby the worst state of preservation may have been generated by compaction or dissolution. We found that echinoids without epibionts do not differ in preservational condition form those which are encrusted. Additionally, it is clear that transport occurred before and after encrustation, which is evident in both abraded encrusters and encrusted and non-encrusted tests.

Abundances of encrusters (all data: $F_{(1,97)}=2.33$, $p=0.129, n=70$; standardized to equal samples size: $F_{(1,56)}=2.41, p=0.125, n=29$ ) and taxa richness (all data: $F_{(1,174)}=0.03, p=0.852, n=126$; standardized to equal samples size: $\left.F_{(1,98)}=0.41, p=0.522, n=50\right)$ do not correlate with the different states of preservation of the echinoids. Another test showed that abundance $\left(R^{2}=\right.$ $0.005, p=0.695, n=29)$ and taxa richness $\left(R^{2}<0.001\right.$, $p=0.954, n=50$ ) are unrelated to echinoid test size.

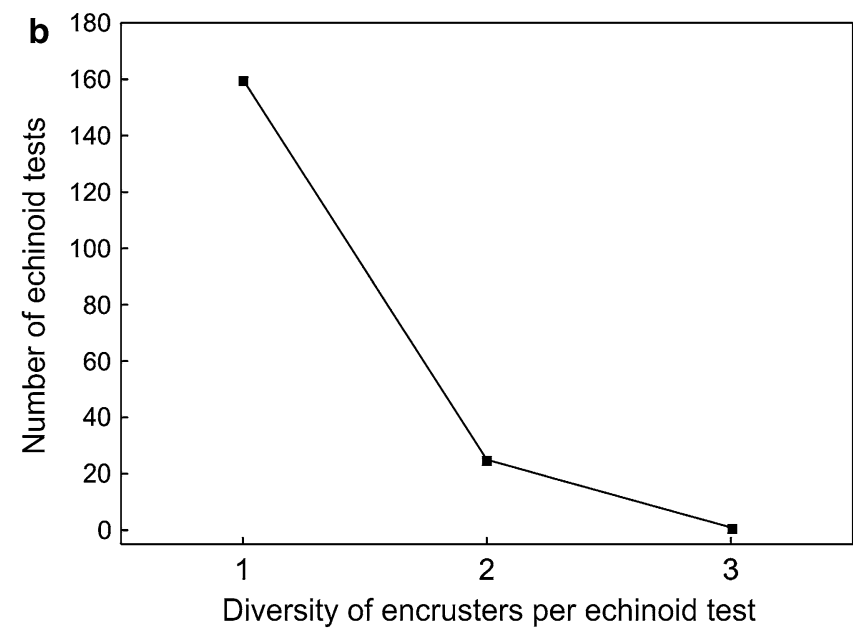




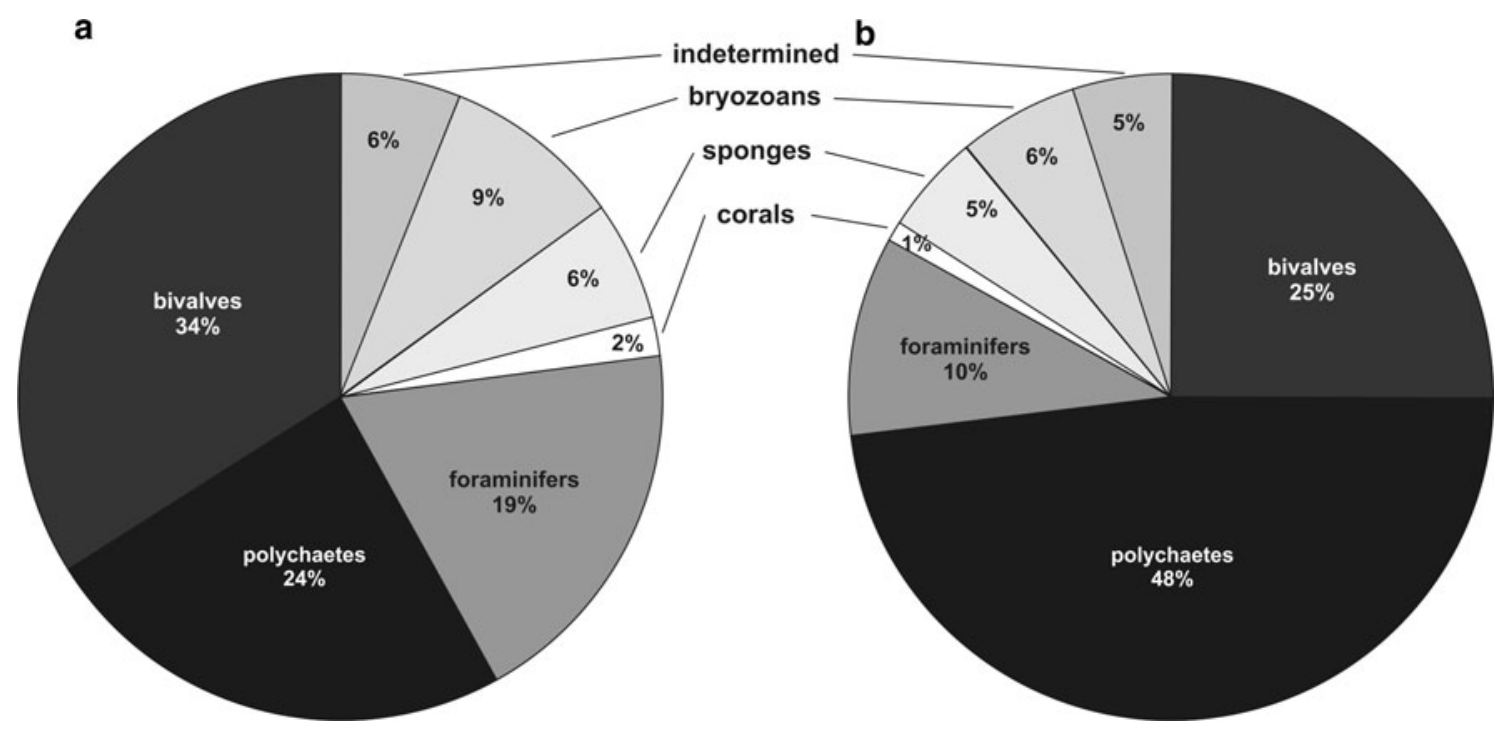

Fig. 10 Percentage of particular encrusting groups in the assemblage according to two sampling variants: number of encrusting individuals (a) and number of encrusted echinoids tests (b)

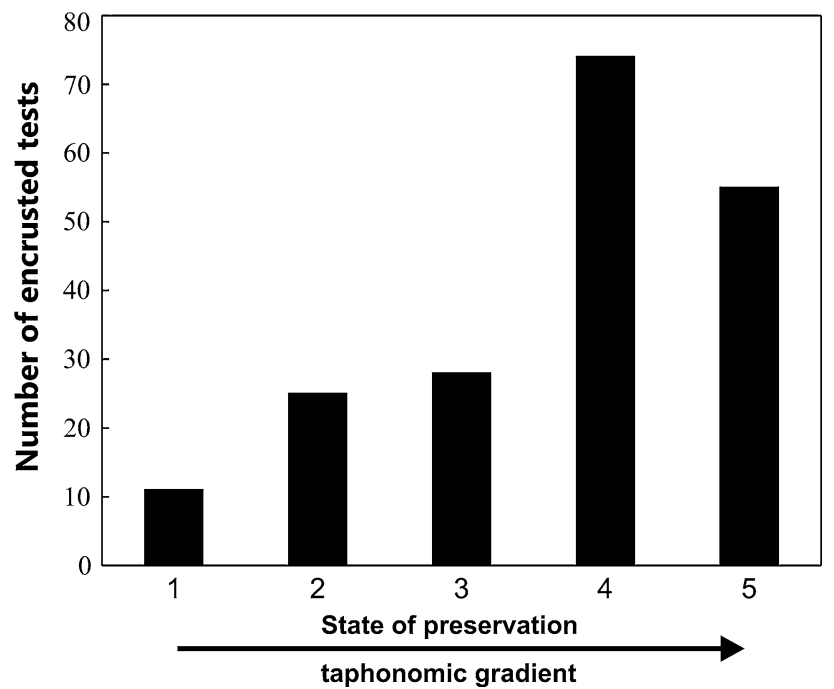

Fig. 11 Relationship between the number of encrusted echinoid tests and their state of preservation ( 1 -complete tests without signs of fragmentation or disarticulation, 2-complete tests with weak taphonomic signatures, 3 - specimens with $>70 \%$ of test preserved, $4-$ test fragments $(>50 \%)$, crushed and/or compacted, 5-less than $50 \%$ of test preserved)

Also abundance and taxa richness are rather poorly correlated with each other $\left(R^{2}=0.24, p<0.001, n=27\right)$. Abundance (Fig. 9a) and taxon richness (Fig. 9b) related to single echinoid tests show a different pattern. All echinoid tests with six epibionts are poorly preserved. Preservational states 1-3 showed a larger variety of encruster abundances. Similarly, with respect to micro-alpha diversity (on single tests), slightly higher levels were found exclusively on poorly preserved hosts. Echinoid tests with highest encruster diversities (i.e., three taxa) all belong to preservational state 4 (see also Fig. 14).

The encrusters were small-sized organisms, exemplified by spirorbins (Fig. 15a) and bivalves (Fig. 15b), rarely exceeding $1 \mathrm{~cm}$ in diameter. The populations are devoid of tiny juveniles, which can be regarded as a preservational bias. The small size of colonizers probably reflects the high mortality of young individuals. The visual inspection of the plot of three measurements of encrusted echinoid tests (Fig. 16) shows that there is no strong preference by the encrusters for test size.

Tests ranging in size from a few $\mathrm{mm}$ to more than $4 \mathrm{~cm}$ were available for colonization. Size variation represents a near-normal distribution. Relationship between encruster sizes and sizes of the host echinoids was not statistically significant for spirorbins $\left(R^{2}=0.001, p=0.939\right)$, but was strongly significant for bivalves $\left(R^{2}=0.72, p<0.001\right)$. Visual inspection showed that, on average, the area of the echinoid test coverage does not exceed a few percent of the total test surface. This could be recognized as opposite to "intensification effect" sensu Pineda and Caswell (1997) and may be called by analogy as "loosening effect". Apart from serpulids, other epibionts, such as three bivalve bases, rarely are in close proximity to each other, suggesting a lack of gregariousness.

Bioclasts apart from the echinoid tests studied here show only occasional encrustation. The co-occurring small regular echinoid Salenocidaris granulosa, was found to be free of epibionts. The numerous marginal plates of goniasterid asteroids at the Glanów section are covered only by serpulids, like those found on the echinoids, which occasionally cover articulation surfaces. The bulk samples, 


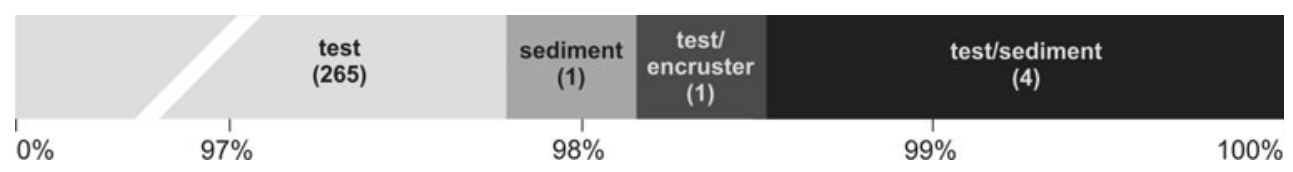

Fig. 12 Percentages of particular types of encrustation (for 271 encrustations). Numbers of encrustation for particular types are given in parentheses

except for some corals, yielded no encrusters similar to those on the slab surfaces. Quartz pebbles were also found to be free of encrusters. These data show that echinoids provided the principal substrates for encrusters.

There are no signs of epibiont succession through time $\left(H_{(3, \mathrm{n}=3,900)}=1.55, p=0.670\right)$, even in the best sampled collection from Glanów. Microencrustation (e.g., Reolid and Gaillard 2007; Reolid et al. 2007) was generally not found in the investigated material with the exception of tiny foraminifera, regarded as microencrusters by some authors.

Interval I at Glanów was probably the oldest sampled and contained sponges, octocorals, and foraminifera, while other taxa appeared in interval II and following intervals. Worthy of mention is the fact that during the first interval only 11 tests were found to be encrusted, while during the next interval more than a hundred tests were encrusted. A distinct encruster bio- and taphofacies could not be recognized. This is probably due to the small number of encrusted tests from localities other than Glanów, and
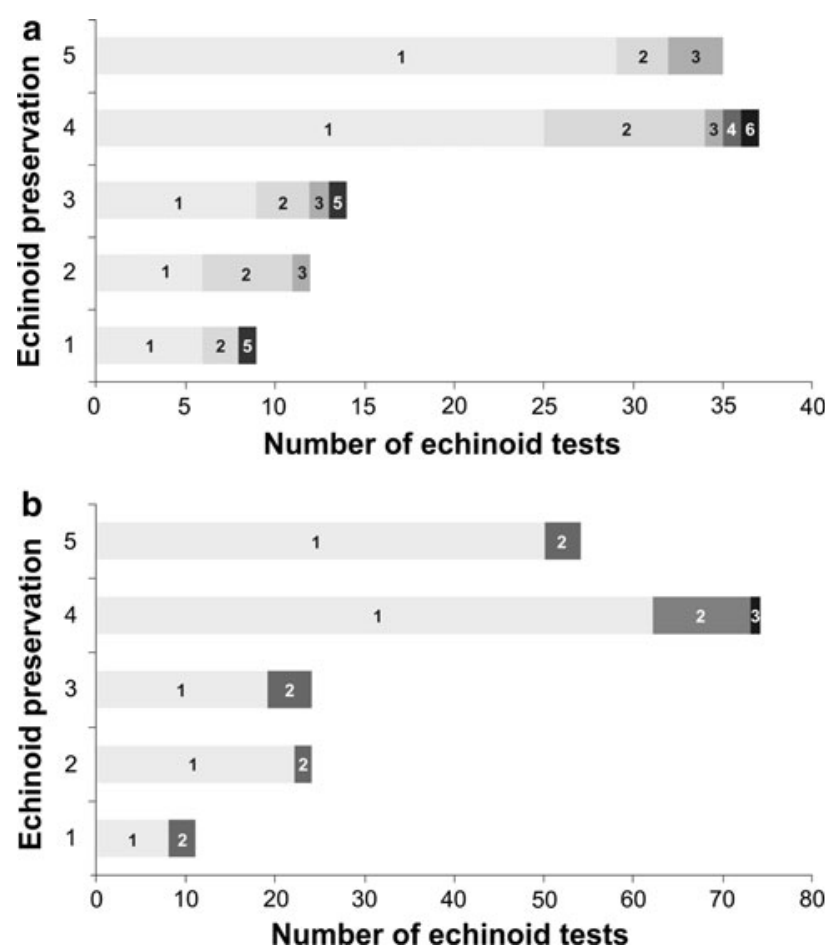

Fig. 13 Abundance $(\mathbf{a} ; n=107)$ and diversity $(\mathbf{b} ; n=187)$ of encrusting organisms in particular taphonomic classes of the host strong homogenization within each sampled interval at Glanów. The same factors may explain the lack of any encruster succession.

\section{Interpretation and discussion}

Patterns of encrustation

Encrustation intensity (EI) is similar to "success of encrustation" sensu Nebelsick et al. (1997) and may be regarded as colonizer-inherent or ecosystem-inherent. This important parameter has implications for reconstructing productivity in the fossil record (e.g., Lescinsky et al. 2002 and references therein; see also Rodland et al. 2004). If tracked through time and space, it can potentially serve to test macroevolutionary and macroecological hypotheses. In the encrusted Polish Turonian echinoids studied here, a rather low intensity of encrustation was observed relative to the number of encrusted echinoid tests. Also evident is the small surface coverage $(0-5 \%)$, i.e., "light encrustation" seen also in some other skeletobionts (e.g., Brandt 1996; Zhang et al. 2009; Key et al. 2010; Rakociński 2011). This contrasts with the "heavy encrustation" (over $50 \%$; e.g., Kudrewicz 1992; Nebelsick et al. 1997; Schneider 2003; Zamora et al. 2008).

EI values vary between particular localities as well as between the two encrusted echinoid species. Of about 300 specimens of small $C$. minimus, only six were encrusted $(\mathrm{EI}=2 \%)$. Assuming that the echinoid tests approximate ideal spheres with a diameter of $3 \mathrm{~cm}$, the collected material provided a substrate of a few square meters for encrustation. If this estimate is restricted to tests with documented encrustation, it gives ca. $2 \mathrm{~m}^{2}$ of an available area for colonization. Of course, this area was not all available at any one time.

Encrustation intensity to date has been largely explained in two ways: as a result of different times of exposure on the sea floor, and of variations in productivity. Additionally, disturbance of the substrate and removal of epibionts from the host have also been taken into account (e.g., Wilson 1985, 1987; Rodland et al. 2006). In the case of the Polish Turonian echinoids, a scenario of low productivity is probable. However, factors such as sediment resuspensions preventing or lowering encrustation intensity as well as pre-occupation of substratum surfaces by unpreservable 


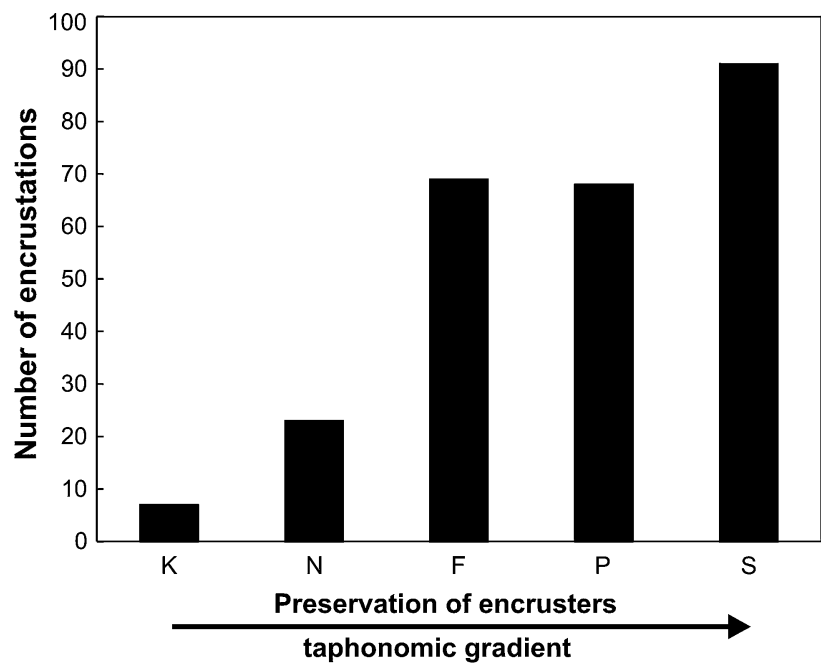

Fig. 14 Relationship between number of encrustations and encruster preservation $(n=258)$. Letters denote state of preservation of encrusters: $K$ complete specimens, $N$ incomplete epibionts, $F$ small fragments, $P$ bases and attachments, $S$ traces of encrustation

encrusters cannot be excluded with certainty on the basis of investigation of fossil material.

\section{Productivity}

Data concerning the relationship between productivity and encrustation intensity is scarce. However, Lescinsky et al. (2002) found a correlation between productivity and encrustation intensity in a study of molluscs from the Java Sea (Indonesia). If productivity was the primary control in the Polish Turonian, we would expect a low to medium intensity of encrustation and low/moderate percent coverage in view of the paleogeographical location and geologic age.

\section{Living host colonization}

The possibility of preferential encrustation of living echinoids (cf. Rodland et al. 2006) may be excluded in our case

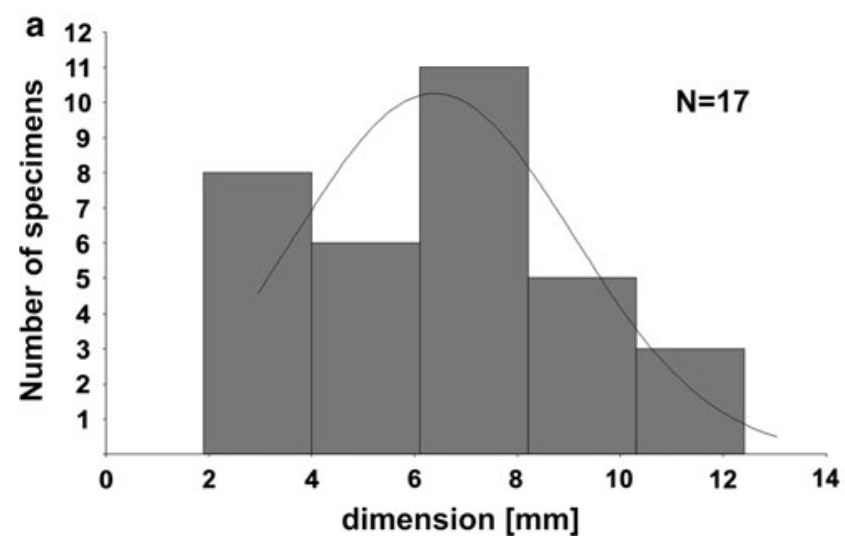

because encrustation of test oral surfaces and periprocts, as well as lack of stereom malformations, shows that the echinoids were dead.

\section{Erasure}

Erasure of epibionts produces a taphonomic artifact (see e.g., Rodland et al. 2006), masking the true intensity of encrustation and abundance of encrusters. However, the "cleaned" substrate may be later re-encrusted. This scenario is excluded here because many of the Polish Turonian echinoids are characterized by the same taphonomic history and the same state of preservation. It is improbable that in two nearly identical echinoids their epibionts, characterized by the same taphonomic properties, were selectively removed. Additionally, the most fragile epibionts (tiny serpulids and foraminifera) are dominant and important components of the assemblage. Thus, the preservation of such delicate forms in great numbers excludes the possibility that encrusters were removed.

\section{Limited exposure}

Intensity of encrustation is often linked with time of exposure of the substratum and taphonomic processes in general are related in some way to the degree of exposure (e.g., Powell et al. 2011). It is predicted that substrates exposed for longer on the sea floor, including redeposited substrates, will have a greater chance to be colonized/ recolonized or more heavily encrusted (e.g., Reolid et al. 2005; Rodland et al. 2006). Also substrate size may be significant for exposure time, with larger substrates being exposed for longer. Recent experiments using artificial settlement panels in the Arctic (e.g., Barnes and Kukliński 2005) have shown a nearly linear correlation between the number of colonizers and time of substrate exposure. They also demonstrated that encrustation is a rather quick

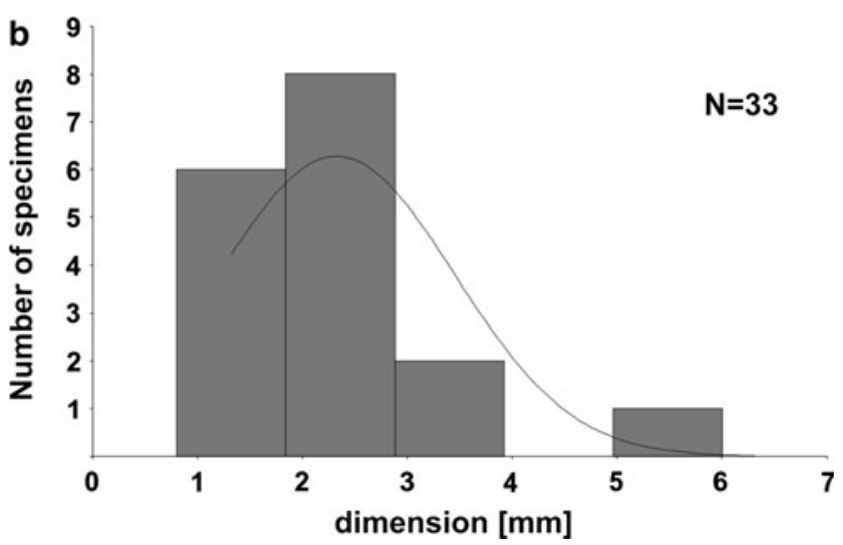

Fig. 15 Size histograms of selected groups of episkeletozoans. a Spirorbins. b Bivalves 

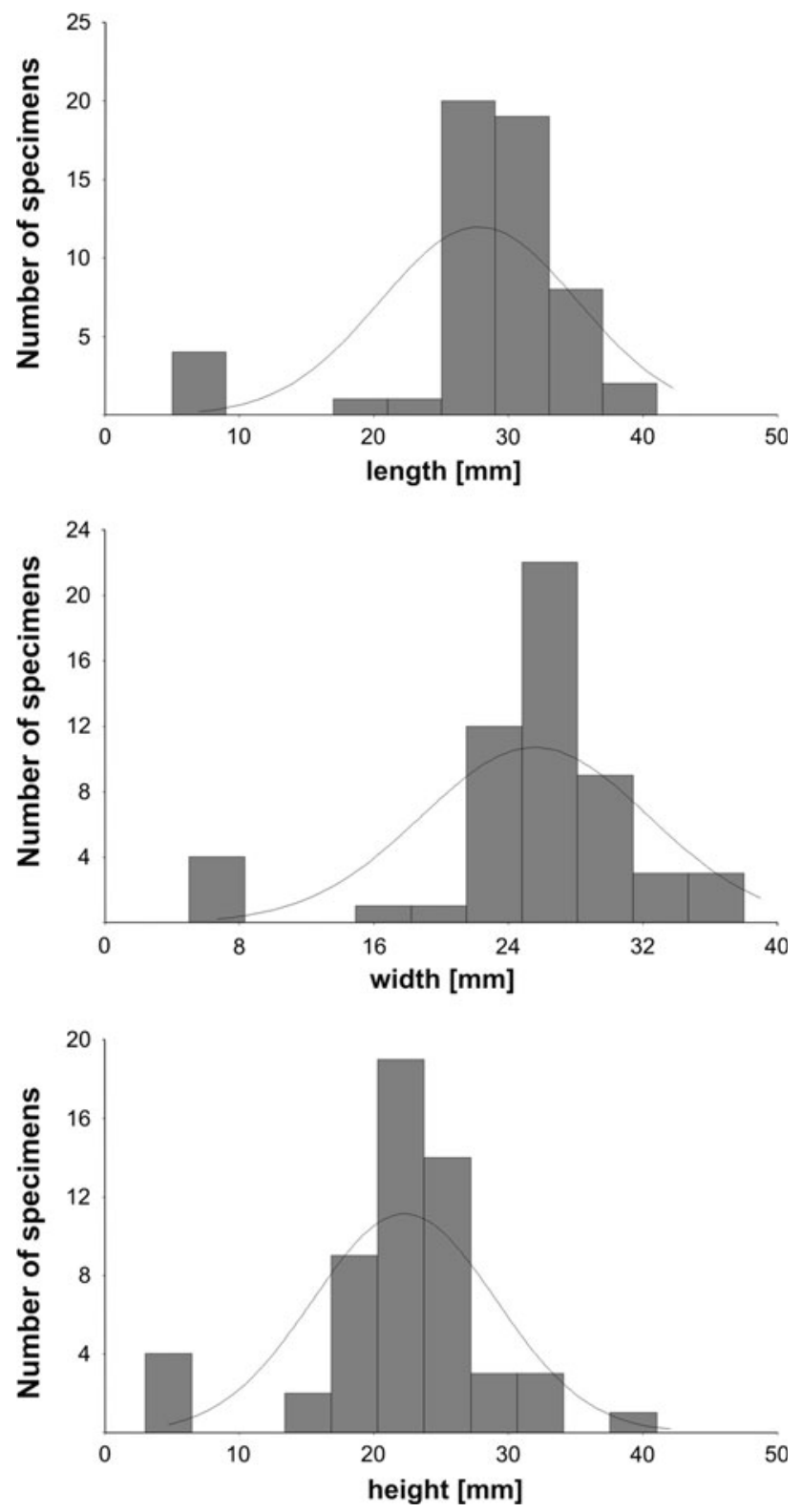

Fig. 16 Size histograms of encrusted echinoid tests $(n=55)$

process. In our case, sedimentation breaks enabling a long persistence of dead echinoids on the sea floor were absent. Redeposition episodes that might have increased the chances of previously non-encrusted echinoids to become re-exposed for colonization are unknown. However, Rodland et al. (2006), based on dated subfossil brachiopods, proved that time of exposure does not matter. Additionally, actualistic data suggest that within a few days the preservable taxa can settle. It is also important that our encrusted echinoids were on the sea floor at the time of death due to their epifaunal mode of life. Quantification of host preservation, although not providing a strong statistical signal, suggests that poorer preservation, partly caused by longer exposure time, is not a primary determinant.

\section{Disturbance}

This process (e.g., Osman 1977; Sousa 1979a, b; Wilson 1985, 1987) may itself explain various parameters, such as percent of coverage or diversity of encrusters but rather not EI. As the substratum was frequently overturned, and probably also the ephemeral echinoid substrate, the latter were encrusted more than once while lying on the sea floor. This is supported by the observation that on some of the echinoid tests, the epibionts are occasionally distributed on different surfaces, occupying two or three opposite poles. Such patterns exclude synchronous colonization. This is because encrustation is a rapid and repetitive process. If continuously overturned, echinoids, together with other biogenic material, would probably be destroyed and never preserved, rather than preserved nonencrusted.

\section{Size, shape, and texture of a substrate}

The model predicts that heterogeneous substrates (i.e., those that are more diverse in shape, texture, lithology, and are larger) should be more densely covered or might be settled by a more diverse fauna (e.g., Santos and Mayoral 2008; Grzelak and Kukliński 2010; Sørensen and Surlyk 2010). This in consequence may also explain the fouling ratio. However, here we argue that the main substrate was relatively homogeneous because it consisted of only one species, showing slight morphological variability. Because our material was nearly homogenous with respect to shape and texture, all the tests would to have had the same probability of being encrusted. We therefore rule out the heterogeneity model as the sole explanation for the present case.

In summary, we conclude that EI here was most probably the result of low productivity. However, the significance of other factors such as brief time of exposure, resuspensions, or disturbance, cannot be excluded unambiguously.

\section{Abundance and diversity of encrusters}

Distribution patterns of encrusters are considered to be determined by both environmental (physical) and biological factors (Perry and Hepburn 2008). These factors are known to act jointly in many instances and are commonly difficult to disentangle. Here, a few most important patterns are discussed.

The reported assemblages of encrusters are of low diversity, the same as the associated benthic organisms at the investigated sites. It is especially evident when biodiversity data is compared with literature sources. For example, Zatoń et al. (2011) noted at least 26 epilithozoan 
taxa on Middle Jurassic hiatus concretions from Poland. Palmer (1982) noted 13 taxa for the most diverse Cretaceous hardground and showed that total species richness at that time was higher than during the Triassic, and lower when compared to the Jurassic. In general terms, Bambach (1977) pointed out that a mean of 7.5 species are expected in Mesozoic high stress communities, while in variable nearshore and open-marine settings, 17 and 25 taxa are predicted, respectively. As was pointed out by McKinney (1996), fossil assemblages of shell-encrusting communities commonly have low diversity (mean $=8$ ). This is comparable to the diversity of fossils in high-stress marine environments, such as the intertidal zone and estuaries for various parts of the Phanerozoic (Bambach 1977). If our values for the higher taxonomic ranks used here are compared to the data of Bambach (1977), the Late Cretaceous encrusters would be placed between high stress and variable nearshore environments. Bambach's (1977) estimation, however, refers to all taxa, not only encrusters. Thus, it is difficult to compare our values directly with his figures. From the Recent, such low values were noted for example from the brackish encrusting environment of the Gdańsk Bay of the Baltic Sea (Grzelak and Kukliński 2010). This suggests that the low diversity of 10 taxa in our case, is the result of substrate homogeneity, as well as of the state of preservation, rather than of the type of substrate or location. Both Palmer's (1982) data and the current study stay in contrast with the data gathered by Žitt and Nekvasilová (1996) who reported 29 and 23 species from Cenomanian/Turonian nearshore settings nearly contemporaneous with our own. Their data, however, like those of Zatoń et al. (2011), also come from substrates which experienced longer exposure on the sea floor, are better preserved, and thus could be resolved to lower taxonomic units. However, our results are in accordance with Witman et al. (2004), who showed that the number of species is a consequence of processes acting on local and regional scales. Importantly, our study also adds to their conclusions that a time dimension in the fossil record must be taken into account. We presented the data using two methods, which are not congruent but suggest a moderate abundance. Abundance, which is variously counted or expressed and may be variously biased, is difficult to compare. Apart from that, we showed a clear dominance of sedentary polychaetes and bivalves and thus confirming Lescinsky's (2001, p. 461) general observation. Žitt and Nekvasilová (1996) also showed that in their nearly contemporaneous assemblages there was a dominance of two associations on their studied rockgrounds: an oyster-bryozoan and a bivalve-foraminifera association. Similarly, OlszewskaNejbert (2007) illustrated a dominance of serpulids and bivalves in the Turonian/Coniacian material.
Size relation between the host and encrusters

The size of the substrate, that is the area for living, was considered in numerous studies as one of the most important factor shaping sessile communities (e.g., Pineda and Caswell 1997; Reolid et al. 2005). In some cases, it is also referred to as the "limited ecospace" (Jagt et al. 2007). Osman (1977) pointed out that differences in diversity and species composition may have resulted solely from size differences of the substratum.

In this study, abundance, but also species richness of encrusters, are independent of echinoid size. In general, such a pattern could be explained as a result of random epibiont recruitment on a post-mortem, homogeneously shaped substratum during a particular time of low productivity, the latter factor being the least important. The investigated echinoids, dominated by one species, were nearly homogeneous in shape, thus we may exclude shape of the substrate as a factor influencing our encruster community. Heterogeneous substratum is more attractive for settlers and thus increases diversity and abundance (e.g., Wilson and Taylor 2001; Zatoń et al. 2011). Our material comes from Cretaceous deposits, where much fewer encrusting taxa are found, as compared to other intervals, where they are more diverse as (e.g., during the Jurassic; Palmer 1982; Lescinsky 2001).

The lack of dominance of a particular size class or the absence of the smallest classes of substrate should reflect a stochastic encrustation, as suggested by a near normal distribution of encrusted tests. This explains the rarity of encrustation of the smallest echinoids, which is especially true for a small C. minimus. This is supported, for example, by Schneider (2003, p. 438), who found that the diameter of the echinoid test with and without epibionts does not differ significantly even in syn vivo encrustation. Using two testing groups, we found that among epibionts there is no host-size selection (=host-size preferences) in spirorbins. By contrast, we found such a correlation with respect to bivalves. This is probably an effect of substrate stability if we assume that bivalves grow slower and need a more stable substrate than spirorbins. For example, Spirorbis needs only 3 days to attain $3 \mathrm{~mm}$ in diameter (Jagt et al. 2007). In our material, in both cases, encrusters developed near-normal populations (Fig. 15), while the lack of smallest size classes could be regarded as a taphonomic bias. We know from visual inspections that very small encrusters are present but too poorly preserved to be measured. In this way it is hard to discuss the mortality pattern in our assemblage, which in the cases of some juvenile foraminifera may be high. Cornell et al. (2003) observed normal populations of edrioasteroids but with a small number of juveniles. They explained such a pattern 
as seasonal recruitment influenced by environmental conditions (see also Taylor and Wilson 2003).

Additionally, our data suggests a low-tier assemblage of encrusters. The suspension-feeding epibionts primarily lived at the scrub layer (sensu Palmer 1982), and only in a few instances at the field and canopy layers, while the ground layer was unexplored. Our reasoning is supported by the size of the hosts, the small grain size of the surrounding sediment and the fact that echinoids were a principal component of the shelled benthos and thus served as the main substrate for secondary tiering in the investigated environments. Only corals profited from a higher level while the other groups such as polychaetes and bryozoans exploited lower levels. Additionally, in many instances, the encrusting organisms in our assemblages did not exceed a tier of even $5 \mathrm{~cm}$, while during Cretaceous higher tiers clearly existed (Bottjer and Ausich 1986).

\section{Comparisons}

When compared with other echinoid-dwelling assemblages and other types of substrates, our assemblages are fairly typical. Similarly to echinoids from other Polish localities, as well as to some other examples (see also e.g., Kidwell and Baumiller 1990; Rose and Cross 1993), echinoids from the Turonian-Coniacian of Kazakhstan (Olszewska-Nejbert 2007) were also mainly encrusted by bivalves and serpulids. Kudrewicz (1992) also mentioned the common occurrence of bivalves and serpulids encrusting echinoid tests, which suggests that this was typical of that time. Zamora et al. (2008) found nearly the same assemblages in the Santonian deposits of Spain.

With some quantitative and qualitative differences, Dzik (1975), Kudrewicz (1992), and Małecki (1982) also found similar encrusters to those noted by us in the Upper Cretaceous deposits of Poland. In contrast to our material, Małecki (1982) observed a high frequency and diversity of octocoral bases on Santonian echinoids. Dzik (1975), in contrast, found a few taxa of bryozoans represented by few individuals encrusting the Cenomanian echinoid tests. In Cenozoic deposits, El-Hedeny (2007) noted the presence of barnacles, oysters, spirorbins, and bryozoans, while Mikša (2009) illustrated the presence of coralline algae, oysters, and serpulids and Nebelsick et al. (1997) reported bryozoans, polychaetes, barnacles and coralline algae. These data, together with those of Santos and Mayoral (2008), suggest that taxonomic turnover in evolutionary time was a major determinant of the composition of particular assemblages, and other factors such as substrate characteristics (its size and shape) were of minor and/or limited significance. This is also strongly supported by Schneider (2003) who reported very different assemblages on Carboniferous individuals.
Thus minor factors such as substrate features only selected or excluded some groups from the available pool and shaped their proportions in particular cases. Our findings, complemented with others from the literature, indicate that the Early Turonian in Poland records the penultimate step in the emergence of "modern-type" encrusting communities. It is the first peak in the abundance of spirorbins after their origination in the Late Jurassic or Early Cretaceous. On Santonian echinoids, Zamora et al. (2008) found spirorbins on $34 \%$ of a total of 100 echinoid specimens. Comparing these cases with ours suggests a higher diversity of encrusters in geologically younger communities due to the presence of algae and barnacles that are lacking in our assemblages. In contrast, our assemblages most probably contain sponges. Our data contrast with those from the Recent, mainly due to the absence of non-preservable groups in the fossil record (Nebelsick et al. 1997), such as hydrozoans found on Mediterranean echinoids. Difference between our assemblage and modern examples is also manifested by the occurrence of sabellids represented by Glomerula. In our Turonian communities, as in other Mesozoic ones (e.g., Vinn and Wilson 2010), sabellids were a dominant encrusting group, while they are low in abundance or even absent in Recent hard substrate communities. Probably they were replaced by other clades such as spirorbins, which are one of the dominant encrusters in modern fouling assemblages around the world. In general, Recent encrusting faunas are dominated by common bryozoans, calcareous polychaetes, sponges, ascidians, hydrozoans, corals, and barnacles (e.g., Bowden et al. 2006). Linse et al. (2008) found 51 species of epibionts belonging to ten classes on echinoids from Antarctic settings, with bryozoans as the most diverse group and polychaetes as the most abundant biota. This is very similar to our case, except for bryozoans which are rare and not diverse in our assemblage.

\section{Conclusions}

Our study is based on a rich new material of echinoids collected from five localities in southern Poland, representing a transect of $35 \mathrm{~km}$ of the Turonian sea. Two species of presumed epibenthic irregular echinoids, C. subrotundus and C. minimus, were found to be encrusted, while other litho- and bioclasts were found to be barren or only rarely encrusted. Encrustation patterns are presented for the first time on echinoneid and holectypoid echinoids and on Turonian echinoids in general, as well as on other hard substrates from the Turonian of Poland.

Encrustation was an entirely post-mortem phenomenon, the abundant dead echinoids forming "shellgrounds" or "echinoid carpets" in a soft-bottom, shallow-marine environment. Dominant encrusters were sabellids and bivalves 
(see also Lescinsky 2001). The assemblages are characterized by a moderate abundance, low diversity, low intensity, and low area coverage (density). We found diversity and abundance of encrusters to be independent of each other, and none of these parameters was related to substrate size. Episkeletozoans represented a low tier at ground and field layers. The encrusting assemblages are quite similar to near contemporaneous ones from the Bohemian Basin, but in fact they are less diverse than the latter assemblages.

Acknowledgments The first author is cordially thankful to numerous colleagues for help in the field work, assisting with photographs, and hospitality, mainly to Maciej Rybicki, Janusz Kucharski, Piotr Sołyga, and Sławomir Warzecha. He is also very grateful to numerous persons, too numerous to list here, for help with the literature organization. The most extensive thanks are to Prof. James Nebelsick, Dr. Paul D. Taylor, Dr. Samuel Zamora, and Dr. Brian Rosen for their thorough insight during the profound pre-review offering many constructive comments, corrections, and remarks towards improving the paper. We are especially grateful to Zofia Dubicka M.Sc. for useful biostratigraphic consultations. We are thankful to Prof. Mark Wilson for his help with recognition of sponges. Great thanks are also to the Editor, Prof. Franz Fürsich, Dr. Olev Vinn, and two anonymous reviewers for valuable comments and corrections of an earlier version of the manuscript. This paper forms an improved part of an unpublished Master Thesis of one of us (Borszcz 2010). We dedicate this paper to the memory of the late Prof. Ryszard Marcinowski, the wellknown Polish Cretaceous palaeontologist and stratigrapher, and yearlong investigator of the localities studied for the present publication. This study has been completed during an investigation grant to PK from the Polish Ministry of Science and Higher Education (No N N304 404038).

Open Access This article is distributed under the terms of the Creative Commons Attribution License which permits any use, distribution, and reproduction in any medium, provided the original author(s) and the source are credited.

\section{References}

Alexandrowicz SW (1954) Turon południowej części Wyżyny Krakowskiej. Acta Geol Polon 4:361-390

Bambach RK (1977) Species richness in marine benthic habitats through the Phanerozoic. Paleobiology 3:152-167

Barnes DKA, Kukliński P (2005) Low colonisation on artificial substrata in arctic Spitsbergen. Polar Biol 29:65-69

Bordeaux YL, Brett CE (1990) Substrate specific associations of epibionts on Middle Devonian brachiopods: implications for paleoecology. Hist Biol 4:221-224

Borszcz T (2010) Akumulacje jeżowców z kredy górnej Polski południowej. Unpublished M.Sc. Thesis, University of Silesia, Faculty of Earth Sciences, Sosnowiec

Borszcz T, Gajerski A, Rakociński M, Szczepańczyk A (2008) Wstępne dane o nagromadzeniu jeżowców z rodzaju Conulus $\mathrm{w}$ profilu dolnego turonu Glanowa (niecka miechowska). Przeg Geol 56:552-556

Bottjer DJ (1982) Paleoecology of epizoans and borings on some Upper Cretaceous chalk oysters from the Gulf Coast. Lethaia $15: 75-84$
Bottjer DJ, Ausich WI (1986) Phanerozoic development of tiering in soft substrata suspension-feeding communities. Paleobiology 12:400-420

Bowden DA, Clarke A, Peck LS, Barnes DKA (2006) Antarctic sessile marine benthos: colonisation and growth on artificial substrata over three years. Mar Ecol Progr Ser 316:1-16

Brandt DS (1996) Epizoans on Flexicaymene [Trilobita] and implications for trilobite paleoecology. J Paleontol 70:442-449

Brett CE (1988) Paleoecology and evolution of marine hard substrate communities; an overview. Palaios 3:374-378

Brett CE, Baird GC (1986) Comparative taphonomy: a key to paleoenvironmental interpretation based on fossil preservation. Palaios 1:207-227

Briggs DEG (1990) Flattening. In: Briggs DEG, Crowther PR (eds) Palaeobiology: a synthesis. Blackwell Publishing, Oxford, pp 244-247

Cieśliński S (1959) Początki transgresji górnokredowej w Polsce (bez Karpat i Śląska). Geol Quart 3:943-964

Cornell SR, Brett CE, Sumrall CD (2003) Paleoecology and taphonomy of an edrioasteroid-dominated hardground association from tentaculitid limestones in the Early Devonian of New York: a Paleozoic rocky peritidal community. Palaios 18:212224

Dadlez R (1989) Epikontynentalne baseny permu i mezozoiku w Polsce. Geol Quart 33:175-198

Dadlez R, Marek S, Pokorski J (eds) (1998) Atlas paleogeograficzny epikontynentalnego permu i mezozoiku w Polsce. Państwowy Instytut Geologiczny, Warszawa, pp 1-7 (pls 75)

Dodd JR, Stanton RJ (1990) Paleoecology. Concepts and applications, Wiley New York

Dzik J (1975) The origin and early phylogeny of the cheilostomatous Bryozoa. Acta Palaeont Polon 20:395-423

El-Hedeny M (2007) Encrustation and bioerosion on Middle Miocene bivalve shells and echinoid skeletons: paleoenvironmental implications. Rev Paléobiol 26:381-389

Fraiser ML (2011) Paleoecology of secondary tierers from Western Pangean tropical marine environments during the aftermath of the end-Permian mass extinction. Palaeogeogr Palaeoclimatol Palaeoecol 308:181-189

Gale AS (2002) Corals. In: Smith AB, Batten DJ (eds) Fossils of the Chalk. Palaeontological Association, London, pp 42-46

Golonka J (2000) Cambrian-Neogene plate tectonic maps. Wydawnictwo Uniwersytetu Jagiellońskiego, Kraków 125 p

Gradziński R (1972) Przewodnik geologiczny po okolicach Krakowa. Wydawnictwa Geologiczne, Warszawa

Grzelak K, Kukliński P (2010) Benthic assemblages associated with rocks in a brackish environment of the southern Baltic Sea. J Mar Biol Assoc UK 90:115-124

Hageman SA, Kaesler RL, Broadhead TW (2004) Fusulinid taphonomy: encrustation, corrasion, compaction and dissolution. Palaios 19:610-617

Hammer Ø, Harper DAT, Ryan PD (2001) PAST: paleontological statistics software package for education and data analysis. Palaeon Electron 4:1-9

Hammond J (1988) Epizoan interactions in the Chalk benthos. Unpublished Ph.D. Thesis, University of Cambridge, Cambridge

Harder T (2009) Marine epibiosis: concepts, ecological consequences and host defence. Springer Ser Biofilms 4:219-231

Hercegová J (1988) Acruliammina, Bdelloidina, and Axicolumella n. gen. (Foraminifera) from the cretaceous transgressive sediments of the Bohemian Massif. Sbornik Geol Ved Paleont 29:145-189

Jäger M (1983) Das Maastricht in Nordwestdeutschland. Serpuliden aus der Schreibkreide. Geol Jb A 68:3-219

Jäger M (2004) Serpulidae und Spirorbidae (Polychaeta sedentaria) aus Campan und Maastricht von Norddeutschland, den 
Niederlanden, Belgien und angrenzenden Gebieten. Geol Jb A 157:121-249

Jagt JWM, Kin A (2010) The phymosomatid echinoid Trochalosoma taeniatum from the Maastrichtian (Upper Cretaceous) of southeast Poland. Acta Geol Polon 60:429-435

Jagt JWM, Salamon MA (2006) The cardiasterid echinoid Hagenowia from the Santonian-Campanian (Upper Cretaceous) in southern Poland. N Jb Paläont Mh 12:78-89

Jagt JWM, Walaszczyk I, Yazykova EA, Zatoń M (2004) Linking southern Poland and northern Germany: Campanian cephalopods, inoceramid bivalves and echinoids. Acta Geol Polon 54:573-586

Jagt JWM, Neumann C, Schulp AS (2007) Bioimmuring Late Cretaceous and Recent oysters: 'A view from within'. Geol Belg $10: 121-126$

Key MM Jr, Schumacher GA, Babcock LE, Frey RC, Heimbrock WP, Felton SH, Cooper DL, Gibson WB, Scheid DG, Schumacher SA (2010) Paleoecology of commensal epizoans fouling Flexicalymene (Trilobita) from the Upper Ordovician, Cincinnati Arch Region, USA. J Paleontol 84:1121-1134

Kidwell SM, Baumiller T (1990) Experimental disintegration of regular echinoids: roles of temperature, oxygen, and decay thresholds. Paleobiology 16:247-271

Kongiel R (1939) Notes pour servir a l'étude des Échinides crétacées de Pologne. 1 Échinides regulieres. Prace Tow Przyj Nauk w Wilnie 13:1-54

Kowalewski M (1990) A hermeneutic analysis of the shell-drilling gastropod predation on mollusks in the Korytnica Clays (Middle Miocene; Holy Cross Mountains, Central Poland). Acta Geol Polon 40:183-213

Kroh A, Smith AB (2010) The phylogeny and classification of postPalaeozoic echinoids. J Syst Palaeont 7:147-212

Kudrewicz R (1992) The endemic echinoid Micraster (Micraster) maleckii Mączyńska, 1979 from the Santonian deposits of Korzkiew near Cracow (southern Poland); their ecology, taphonomy and evolutionary position. Acta Geol Polon 42:123-134

Kudrewicz R, Olszewska-Nejbert D (1997) Upper cretaceous"Echinoidlagerstätten" in the Kraków area. Ann Soc Geol Polon 67:1-12

Kukliński P (2009) Ecology of stone-encrusting organisms in the Greenland Sea-a review. Polar Res 28:222-237

Lescinsky HL (1993) Taphonomy and paleoecology of epibionts on the scallops Chlamys hastata (Sowerby 1843) and Chlamys rubida (Hinds 1845). Palaios 8:267-277

Lescinsky HL (1997) Epibiont communities: recruitment and competition on North American Carboniferous brachiopods. J Paleontol 71:34-53

Lescinsky HL (2001) Epibionts. In: Briggs DEG, Crowther PR (eds) Palaeobiology II. Blackwell, Oxford, pp 464-468

Lescinsky HL, Edinger E, Risk M (2002) Mollusc shell encrustation and bioerosion rates in a modern epeiric sea: taphonomic experiments in the Java Sea, Indonesia. Palaios 17:171-191

Linse K, Walker LJ, Barnes DKA (2008) Biodiversity of echinoids and their epibionts around the Scotia Arc, Antarctica. Antarctic Sci 20:227-244

Mączyńska S (1958) Jeżowce rodzaju Discoidea z cenomanu i turonu okolic Krakowa, Miechowa i Wolbromia. Pr Muz Ziemi 2:81-115

Mączyńska S (1984) Class Echinoidea Leske, 1778. In: Malinowska L (ed) Budowa Geologiczna Polski, Tom 3. Atlas skamieniałości przewodnich i charakterystycznych, Część 2c, Mezozoik, Kreda. Wydawnictwa Geologiczne, Warszawa, pp 435-461

Małecki J (1982) Bases of upper cretaceous octocorals from Poland. Acta Palaeont Polon 27:65-75

Marcinowski R (1970) The Cretaceous transgressive deposits east of Częstochowa (Polish Jura Chain). Acta Geol Polon 20:413-449
Marcinowski R (1972) Belemnites of the genus Actinocamax Miller, 1823 from the Cenomanian of Poland. Acta Geol Polon $22: 247-256$

Marcinowski R (1974) The transgressive Cretaceous (Upper Albian through Turonian) deposits of the Polish Jura Chain. Acta Geol Polon 24:117-217

Marcinowski R, Gasiński AM (2002) Cretaceous biogeography of epicratonic Poland and Carpathians. In: Michalik J (ed) Tethyan/ boreal cretaceous correlation. Mediterranean and boreal cretaceous paleobiogeographic areas in Central and Eastern Europe. VEDA, Publishing House of the Slovak Academy of Sciences, Bratislava, Bratislava, pp 95-114

Marcinowski R, Radwański A (1983) The mid-cretaceous transgression onto the Central Polish Uplands (marginal part of the Central European Basin). Zitteliana 10:65-95

McKinney FK (1996) Encrusting organisms on co-occurring disarticulated valves of two marine bivalves: comparison of living assemblages and skeletal residues. Paleobiology 22:543-567

Mikša G (2009) The sand dollar Parascutella (Echinoidea) in the Late Badenian of Croatia. Riv Ital Paleont Stratigr 115:101-109

Nebelsick JH (1996) Encrustation of small substrates in Tertiary limestones and their importance for carbonate sedimentation. Göttinger Arb Geol Paläont Sb 2:161-167

Nebelsick JH, Schmid B, Stachowitsch M (1997) The encrustation of fossil and Recent sea-urchin tests: ecological and taphonomic significance. Lethaia 30:271-284

Olszewska-Nejbert D (2007) Late Cretaceous (Turonian-Coniacian) irregular echinoids of western Kazakhstan (Mangyshlak) and southern Poland (Opole). Acta Geol Polon 57:1-87

Osman RW (1977) The establishment and development of a marine epifaunal community. Ecol Monogr 47:37-63

Palmer TJ (1982) Cambrian to cretaceous changes in hardground communities. Lethaia 15:309-323

Perry CT, Hepburn LJ (2008) Syn-depositional alteration of coral reef framework through bioerosion, encrustation and cementation: taphonomic signatures of reef accretion and reef depositional events. Earth-Sci Rev 86:106-144

Peryt D (1980) Planktic foraminifera zonation of the upper cretaceous in the middle Vistula valley, Poland. Palaeont Polon 41:3-101

Pineda J, Caswell H (1997) Dependence of settlement rate on suitable substrate area. Mar Biol 129:541-548

Popiel-Barczyk E (1958) Jeżowce z rodzaju Conulus z turonu okolic Krakowa, Miechowa i Wolbromia. Pr Muz Ziemi 2:41-79

Powell EN, Brett CE, Parsons-Hubbard KM, Callender WR, Staff GM, Walker SE, Raymond A, Ashton-Alcox KA (2011) The relationship of bionts and taphonomic processes in molluscan taphofacies formation on the continental shelf and slope: eightyear trends: gulf of Mexico and Bahamas. Facies 57:15-37

Pugaczewska H (1965) Les organismes sedentaires sur les rostres des Belemnites du Crétacé supérieur. Acta Palaeont Polon 10:73-95

Radwańska U (1996) Tube-dwelling polychaetes from some upper cretaceous sequences of Poland. Acta Geol Polon 46:61-80

Radwański A (1965) Procesy wciskowe w osadach klastycznych i oolitowych. Rocznik Pol Tow Geol 35:179-210

Rakociński M (2011) Sclerobionts on upper Famennian cephalopods from the Holy Cross Mountains, Poland. Palaeobiodiv Palaeoenvir 91:63-73

Reolid M, Gaillard C (2007) Microtaphonomy of bioclasts and paleoecology of microencrusters from Upper Jurassic spongiolithic limestones (External Prebetic, Southern Spain). Facies 53:97-112

Reolid M, Gaillard C, Olóriz F, Rodríguez-Tovar FJ (2005) Microbial encrustation from the Middle Oxfordian-earliest Kimmeridgian lithofacies in the Prebetic Zone (Betic Cordillera, southern Spain): characterization, distribution and controlling factors. Facies 50:529-543 
Reolid M, Gaillard C, Lathuilière B (2007) Microfacies, microtaphonomic traits and foraminiferal assemblages from Upper Jurassic oolitic-coral limestones: stratigraphic fluctuations in a shallowing-upward sequence (French Jura, Middle Oxfordian). Facies 53:553-574

Richardson-White S, Walker SE (2011) Diversity, taphonomy and behavior of encrusting foraminifera on experimental shells deployed along a shelf-to-slope bathymetric gradient, Lee Stocking Island, Bahamas. Palaeogeogr Palaeoclimatol Palaeoecol 312:305-324

Rodland DL, Kowalewski M, Carroll M, Simões MG (2004) Colonization of a 'Lost World': encrustation patterns in modern subtropical brachiopod assemblages. Palaios 19:381-395

Rodland DL, Kowalewski M, Carroll M, Simões MG (2006) The temporal resolution of epibiont assemblages: are they ecological snapshots or overexposures? J Geol 114:313-324

Ronowicz M, Włodarska-Kowalczuk M, Kukliński P (2008) Factors influencing hydroid (Cnidaria, Hydrozoa) biodiversity and distribution in Arctic kelp forests. J Mar Biol Assoc UK 88:1567-1575

Rose EPF, Cross NF (1993) The chalk sea urchin Micraster: microevolution, adaptation and predation. Geol Today 5:179-186

Rutkowski J (1965) Senon okolicy Miechowa. Rocznik Pol Tow Geol $35: 2-52$

Salamon MA, Gorzelak P, Borszcz T, Gajerski A, Kaźmierczak J (2009) A crinoid concentration Lagerstätte in the Turonian (Late Cretaceous) Conulus Bed (Miechów- Wolbrom area, Poland). Geobios 42:351-357

Santos AG, Mayoral EJ (2008) Colonization by barnacles on fossil Clypeaster: an exceptional example of larval settlement. Lethaia 41:317-332

Schneider CL (2003) Hitchhiking on Pennsylvanian echinoids: epibionts on Archaeocidaris. Palaios 18:435-444

Smith AB (1988) Echinoids. In: Smith AB, Paul CRC, Gale AS, Donovan SK (eds) Cenomanian and Lower Turonian echinoderms from Wilmington, south-east Devon, England. Bull Brit Mus (Nat Hist) Geol 42:16-188

Smith AM, Nelson CS (2003) Effects of early sea-floor processes on taphonomy of temperate shelf skeletal carbonate deposits. EarthSci Rev 63:1-31

Smith AB, Wright CW (1999) British Cretaceous echinoids. Part 5, Holectypoida, Echinoneoida. Palaeontogr Soc Monogr 153:343390

Smith AB, Gale AS, Monks NEA (2001) Sea-level change and rock record bias in the Cretaceous: a problem for extinction and biodiversity studies. Paleobiology 27:241-253

Sørensen AM, Surlyk F (2010) Palaeoecology of tube-dwelling polychaetes on a Late Cretaceous rocky shore, Ivo Klack (Skane, southern Sweden). Cret Res 31:553-566

Sousa WP (1979a) Experimental investigations of disturbance and ecological succession in a rocky intertidal algal community. Ecol Monogr 49:227-254

Sousa WP (1979b) Disturbance in marine intertidal boulder fields: the nonequilibrium maintenance of species diversity. Ecology 60:1225-1239

Sujkowski Z (1926) O utworach jurajskich, kredowych i czwartorzędowych okolic Wolbromia. Spraw Państw Inst Geol 3:382-433

Taylor PD (1979) Palaeoecology of the encrusting epifauna of some British Jurassic bivalves. Palaeogeogr Palaeoclimatol Palaeoecol 28:241-262

Taylor PD, Sequeiros L (1982) Toarcian bryozoans from Belchite in north-east Spain. Bull Brit Mus (Nat Hist) Geol Ser 37:117-129
Taylor PD, Wilson MA (2002) A new terminology for marine organisms inhabiting hard substrates. Palaios 17:522-525

Taylor PD, Wilson MA (2003) Palaeoecology and evolution of marine hard substrate communities. Earth-Sci Rev 62:1-103

Vinn O, Taylor PD (2007) Microconchid tubeworms from the Jurassic of England and France. Acta Palaeontol Polon 52:391-399

Vinn O, Wilson MA (2010) Sabellid-dominated shallow water calcareous polychaete tubeworm association from the equatorial Tethys Ocean (Matmor Formation, Middle Jurassic, Israel). N Jb Geol Paläont, Abh 258:31-38

Wahl M (1989) Marine epibiosis. I. Fouling and antifouling: some basic aspects. Mar Ecol Progr Ser 58:175-189

Wahl M (ed) (2009) Marine hard bottom communities: patterns, dynamics, diversity, and change. Springer Ser Ecol Stud 206:1420

Walaszczyk I (1992) Turonian through Santonian deposits of the Central Polish Upland; their facies development, inoceramid paleontology and stratigraphy. Acta Geol Polon 42:1-122

Wilson MA (1985) Disturbance and ecologic succession in an Upper Ordovician cobble dwelling hardground fauna. Science 228:575577

Wilson MA (1987) Ecological dynamics on pebbles, cobbles, and boulders. Palaios 2:594-599

Wilson MA, Taylor PD (2001) Palaeoecology of hard substrate faunas from the Cretaceous Qahlah Formation of the Oman Mountains. Palaeont 44:21-41

Witman JD, Etter RJ, Smith F (2004) The relationship between regional and local species diversity in marine benthic communities: a global perspective. Proc Nat Acad Sci USA 101:1566415669

Włodarska-Kowalczuk M, Kędra M (2007) Surrogacy in natural patterns of benthic distribution and diversity: lower taxonomic resolution versus indicator groups. Mar Ecol Prog Ser 352:53-63

Zamora S, Mayoral E, Gámez Vintaned JA, Bajo S, Espílez E (2008) The infaunal echinoid Micraster: taphonomic pathways indicated by sclerozoan trace and body fossils from the Upper Cretaceous of northern Spain. Geobios 41:15-29

Zaręczny S (1878) O średnich warstwach kredowych w krakowskim okręgu. Spraw Komis Fizjogr Akad Umiejętn 12:176-246

Zatoń M, Vinn O (2011) Microconchids and the rise of modern encrusting communities. Lethaia 44:5-7

Zatoń M, Machocka S, Wilson MA, Marynowski L, Taylor PD (2011) Origin and paleoecology of Middle Jurassic hiatus concretions from Poland. Facies 57:275-300

Zhang Z, Han J, Wang Y, Emig CC, Shu D (2009) Epibionts on the lingulate brachiopod Diandongia from the Early Cambrian Chengjiang Lagerstätte, South China. Proc R Soc Lond B 277:175-181

Žitt J, Nekvasilová O (1996) Epibionts, their hard-rock substrates, and phosphogenesis during the Cenomanian-Turonian boundary interval (Bohemian Cretaceous Basin, Czech Republic). Cret Res 17:715-739

Zuschin M, Baal C (2007) Large gryphaeid oysters as habitats for numerous sclerobionts: a case study from the northern Red Sea. Facies 53:319-327

Zuschin M, Stachowitsch M, Pervesler P, Kollmann H (1999) Structural features and taphonomic pathways of a high-biomass epifauna in the northern Gulf of Trieste, Adriatic Sea. Lethaia 32:299-317

Zuschin M, Stachowitsch M, Stanton RJ Jr (2003) Patterns and processes of shell fragmentation in modern and ancient marine environments. Earth Sci Rev 63:33-82 